\title{
Research on English language teaching and learning in Argentina (2014-2018)
}

\section{Introduction}

In 2016, Language Teaching published a review of research on English language teaching (ELT) and learning in Argentina between 2007 and 2013 (Porto, Montemayor-Borsinger, \& López-Barrios, 2016). This review was the first to represent Latin America in the journal. The review included an overview of the Argentine system of education and language education with a focus on English. The authors organised and analysed the works of Argentine educators published in Argentinian outlets around the following topics: (1) imagination, emotion and affect, (2) interculturality, (3) teacher education and professional development, (4) content and language integrated learning (CLIL) and interdisciplinarity, (5) digital technologies, (6) individual learner differences, (7) language skills, (8) learning language systems, (9) English for academic and specific purposes, (10) testing, assessment, and evaluation, and last (11) materials and course design. The authors concluded that such a diversity of topics exhibited the multiplicity of interests found in the ELT professional community in Argentina.

As a continuation to that article, the aim of this review is to analyse the ELT research carried out and published in Argentina between 2014 and 2018. On this occasion 115 publications were analysed in terms of topic and research methodologies. First, ELT in Argentina is briefly described (for a detailed report see Porto 2014 and Porto et al. 2016). Second, we describe the decisions and criteria for creating the corpus. We then examine the papers according to nine topics, which we list later. Last, we synthesise commonalities and differences in terms of topics and research practices with the previous review (Porto et al., 2016) and put forward implications for future reviews and empirical studies.

This is a peer-reviewed, author-accepted manuscript of the following research article: Porto, M., López-Barrios, M., \& Banegas, D. (2021). Research on English language teaching and learning in Argentina (2014-2018). Language Teaching, 1-33. 


\section{English language teaching in Argentina}

According to federal agreements on curriculum guidelines (Consejo Federal de Educación, 2012), the teaching of foreign languages in the state sector often includes English, French, German, Italian, and Portuguese among others (e.g., Chinese or Mapudungun) and it should be guided by an intercultural and plurilingual perspective that enables learners to develop a comprehensive sociocultural and critical identity. While several languages might be considered, in practice English is almost exclusively selected as the foreign language of instruction given its international status (Porto, 2014). The private sector may include other languages and offer provision in more than two or three languages at the same time.

In a country with a decentralised educational system, each province has the autonomy to delineate their own curriculum for kindergarten, primary, secondary, and, tertiary education. Drawing on federal agreements (Consejo Federal de Educación, 2012), English is a mandatory subject as from Year 4 in primary education in most provinces (provision depends on budget possibilities and teaching workforce supply) and across the six years of secondary education. It is often allocated two or three weekly hours per each school year (March to November) and teachers are suggested to follow a communicative approach to ELT. In practice, teachers may favour grammar teaching around which vocabulary, language functions, and language skills are built. They also exhibit a tendency to employ a global coursebook as the main teaching material regardless of whether it aligns with the curriculum. It should be noted that there are no national or regional exams for any subjects in Argentina.

In the case of higher education, university courses offer English language courses framed as English for Specific or Academic Purposes (ESP - EAP) aligned with the minors or majors in which students are enrolled. A common feature is to favour reading comprehension and systematic use of Spanish (usually the students' L1) as a central scaffolding tool for L2 learning.

\section{The corpus: scope and inclusion criteria}

The inputs for this review originate in three main sources: conference proceedings, academic journals and edited collections published between 2014 and 2018. Inclusion criteria follow those established for the previous review:

This is a peer-reviewed, author-accepted manuscript of the following research article: Porto, M., López-Barrios, M., \& Banegas, D. (2021). Research on English language teaching and learning in Argentina (2014-2018). Language Teaching, 1-33. 
we decided to consider research whose quality, scope and relevance were consistent with current topics and trends in ELT globally but involved work using local data on local issues and topics. Furthermore, we exclude from this review any Argentinean authors who publish internationally. (Porto et al., 2016, pp. 361-362)

And because we herein review empirical research related to the learning and teaching of English as a foreign language (EFL) we also disregarded

(a) papers focusing on the description and analysis of specific literary works, or monolingual or contrastive descriptions of English whose aim was not specifically pedagogic, and (b) papers describing a theoretical perspective or reporting a given experience or making recommendations. (Porto et al., 2016, p. 362)

Our initial task consisted in tracing the relevant sources from which we would select the corpus. Due to a lack of academic databases specialised in published research related to the teaching and learning of foreign languages in Argentina, we examined the websites of universities and the main colleges of education with foreign language programs, as well as those of professional organisations catering for EFL education in search for their academic publications. As academic journals specialised in foreign language education are scarce in Argentina, related research is often published in journals from an education department or in those with a broader interest in language and linguistics.

Once the relevant publications were tracked (14 journals, 22 conference proceedings, and two edited collections), we concentrated on the main articles, excepting forewords and book reviews in journals, and scanned the titles in search for contributions that conformed with the inclusion criteria listed above, which resulted in a list with 792 possible research items. Next, we read the abstracts and further reduced the corpus to 160 items, composed as follows: 91 articles from 16 conference proceedings (57\% of the sources), 62 from eight This is a peer-reviewed, author-accepted manuscript of the following research article: Porto, M., López-Barrios, M., \& Banegas, D. (2021). Research on English language teaching and learning in Argentina (2014-2018). Language Teaching, 1-33. 
academic journals (39\%) and seven articles from two edited collections (4\%) (Table 1). In the process of writing the review, we discarded about one fourth of the articles, thus reducing the sources to 115 items, as on closer inspection we detected some deficiencies in the methodology or that the paper dealt with a study or data already reported in another contribution in the corpus.

Table 1. Corpus sources and data culling.

\begin{tabular}{lccc}
\hline \multicolumn{1}{c}{ Sources } & $\begin{array}{c}\text { Number of articles in } \\
\text { initial database }\end{array}$ & $\begin{array}{c}\text { Number of } \\
\text { articles selected }\end{array}$ & $\begin{array}{c}\text { Number of articles } \\
\text { considered for review }\end{array}$ \\
\hline $\begin{array}{l}\text { Conference } \\
\text { proceedings }\end{array}$ & 440 & 91 & 73 \\
$\begin{array}{l}\text { Academic } \\
\text { journals }\end{array}$ & 335 & 62 & 37 \\
$\begin{array}{l}\text { Edited } \\
\text { collections }\end{array}$ & 17 & 7 & 5 \\
\hline Totals & 792 & 160 & 115 \\
\hline
\end{tabular}

Most of the conference proceedings originate in academic events organised by a university or a college of education or a professional organisation. Most of the conferences have a foreign language education orientation, while a few deal with a broader variety of linguistic topics. Of 18 conferences included in this review, four are long-established events that were reported in the 2007-2013 review. These conferences are listed in order of quantity of papers reviewed herein:

- $15^{\text {th }}$ edition of the Jornadas de Enseñanza de Lenguas Extranjeras en el Nivel This is a peer-reviewed, author-accepted manuscript of the following research article: Porto, M., López-Barrios, M., \& Banegas, D. (2021). Research on English language teaching and learning in Argentina (2014-2018). Language Teaching, 1-33. 
Superior (JELENS), organised by a committee of modern language teachers in higher education;

$39^{\text {th }}$ to $43^{\text {rd }}$ annual conferences of the Argentine Federation of EFL Teacher Associations (Federación argentina de asociaciones de profesores de inglés, FAAPI);

$4^{\text {th }}$ conference of the 'J.R. Fernández' School of Education in Foreign Languages in Buenos Aires;

- $6^{\text {th }}$ edition of the EFL Conference Jornadas de actualización en la enseñanza del inglés organised by the Universidad Nacional de San Juan.

Additionally, we included papers from six conferences organised by the languages departments of the national universities of Comahue, Litoral, Río Cuarto, Río Negro, Tucumán and Villa María, and we also reviewed papers read at the $14^{\text {th }}$ and $15^{\text {th }}$ conferences of the Argentine Linguistics Society (Sociedad argentina de estudios lingüísticos, SAEL), whose proceedings were published in a series of edited collections. The selection procedures of these conferences involve a blind peer-review process with the participation of national specialists.

Papers from a total of eight academic journals were considered for this review. Five of them belong to the foreign language education or education sciences departments of universities or colleges of education:

Cronía (Facultad de Ciencias Humanas - Universidad Nacional de Río Cuarto), 1997 to date;

Lenguas V;vas (Instituto de Enseñanza Superior en Lenguas ‘J. R. Fernández’,

This is a peer-reviewed, author-accepted manuscript of the following research article: Porto, M., López-Barrios, M., \& Banegas, D. (2021). Research on English language teaching and learning in Argentina (2014-2018). Language Teaching, 1-33. 
Buenos Aires). Started in 1957 and has appeared irregularly since then;

Lenguas y Culturas Extranjeras - LyCE Estudios (Instituto de investigación en lenguas y culturas extranjeras, Facultad de Filosofía y Humanidades, Universidad Nacional de Cuyo). Started as Revista de Lenguas Extranjeras in 1970;

Revista de Educación (Facultad de Humanidades, Universidad Nacional de Mar del Plata), 2010 to date;

Revista digital de políticas lingüísticas: (Asociación de Universidades Grupo Montevideo, Universidad Nacional de Córdoba, Facultad de Lenguas), 2009 to date;

whilst three journals are published by two professional organisations:

Argentinian Journal of Applied Linguistics (AJAL), published by the Argentine Federation of EFL Teacher Associations (FAAPI), 2013 to date.

ARTESOL ESP Journal (2011 to date) and ARTESOL EFL Journal (2014 to date), both published by the Argentinian chapter of TESOL.

All journals operate on a blind peer-review process involving both national and international reviewers.

In the sections which follow, the publications are organised and reviewed according to nine topics: (1) interculturality and citizenship, (2) language teacher education and professional development, (3) technology-enhanced language learning, (4) learner differences, (5) language skills development, (6) language systems, (7) EAP and ESP, (8) assessment, and (9) language curriculum development. These topics, randomly sequenced, This is a peer-reviewed, author-accepted manuscript of the following research article: Porto, M., López-Barrios, M., \& Banegas, D. (2021). Research on English language teaching and learning in Argentina (2014-2018). Language Teaching, 1-33. 
represent the thematic areas which emerged during the categorisation of each paper. It should be clarified that some papers fitted into more than one category (e.g. language skills and ESP). In such cases, a paper was categorised under the broader theme for the sake of organisation of this review (e.g. a paper about reading authentic materials was included under reading).

\section{The intercultural and citizenship dimensions of ELT}

Recent developments in foreign language education, which evolved over the past decade, point to the need to complement its instrumental and educational purposes, which comprise linguistic, communicative and disciplinary/content aims on the one hand, and intercultural and citizenship aims on the other (Byram, 2008; Byram et al., 2017). These needs are relevant to students of world languages in schools and universities in different settings and they are also necessary in the education of future professionals in the field of languages (teachers, translators, interpreters, researchers). In our previous review article (Porto et al., 2016), one theme that emerged was the intercultural dimension of ELT, but with very few articles addressing the topic and no reference at all to the citizenship dimension. The scenario has not changed much, with only six papers in this section now. This finding is significant because it means that the local academia is not addressing an area that Byram considers to be inescapable, namely the conceptualisation of intercultural citizenship as an "educational philosophy" (Byram, 2018, p.73) rather than an optional approach or pedagogy, relevant as well in the preparation of future professionals of the language. This is not a limitation that applies only to Argentina and Byram $(2014,2016)$ has pointed out the need for the routinisation and systematisation of an intercultural citizenship basis for world language education, which is yet to be explored locally.

Salcedo and Sacchi (2014), Basabe, Tamagni Baigorria and Schiel Yicarean (2016) This is a peer-reviewed, author-accepted manuscript of the following research article: Porto, M., López-Barrios, M., \& Banegas, D. (2021). Research on English language teaching and learning in Argentina (2014-2018). Language Teaching, 1-33. 
and Braun (2015) carried out investigations which help understand this limitation in our local context. Salcedo and Sacchi (2014) explored the beliefs of 25 in-service teachers in elementary or high schools in Río Cuarto in Córdoba province about culture, the teaching of culture, and their training to teach culture. Using a mixed methods design (a questionnaire and interviews) their findings showed that participants considered culture an integral part of language learning and teaching and expressed feeling well-prepared to address this dimension. However, the in-depth interviews showed that in the classroom, they tended to focus on the cultural products (e.g., food, music, dances) of English speaking communities, which is a superficial approach, and acknowledged that their pedagogical knowledge was insufficient. Similarly, Braun's (2015) action research, designed as curriculum development for the enhancement of intercultural competence in primary state schools in La Pampa, showed that students tended to consider the foreign culture as superior to their own. As Braun herself acknowledges, this finding is worrisome but nonetheless does not cloud the promising results: the surveys administered to the primary school students and the interviews with the English teachers and headmistresses indicated a positive impact on students' motivation and learning. In turn, Basabe, Tamagni Baigorria and Schiel Yicarean (2016) designed an experiential visual literacy, arts and literature based, pedagogic proposal for the ELTE (English language teacher education) programme in La Pampa province. Thirty-two student teachers in their early twenties enrolled in the course Cultural Studies in 2014, explored national cultures through art (paintings, films, video clips and magazine covers) and represented their views on globalisation using selfies in combination with drawing, painting, and poster-making during 17 weeks. Findings showed that while participants engaged with the proposed tasks during the course, they did not recall them as significant in the deferred feedback they provided. Considering the importance of arts-based approaches to meaning making acknowledged in the literature (Rowsell \& Vietgen, 2017), this study is alone in

This is a peer-reviewed, author-accepted manuscript of the following research article: Porto, M., López-Barrios, M., \& Banegas, D. (2021). Research on English language teaching and learning in Argentina (2014-2018). Language Teaching, 1-33. 
attempting to explore them within English language education and further research is clearly needed. Sadly, the authors remark that they did not examine "the role of English in the activities under consideration" and this is a limitation. In intercultural citizenship theory and pedagogy (Byram et al., 2017), within which arts-based pedagogies are at the forefront, the linguistic and communicative dimensions are not forgotten but rather complement the intercultural and citizenship tenets.

In a pioneering large-scale longitudinal action research study epistemologically grounded in critical social positioning and involving three secondary schools in the city of Santa Fe, Coudannes Aguirre and Andelique (2016) describe a complex design that involved the creation of ten interdisciplinary projects especially developed to cater for the theme identity and citizenship in the Latin American context, chosen on the basis of a survey administered to the students attending these schools. Students of a general didactics course at the local national university observed lessons in these schools, collected data, administered open questionnaires to the students and interviewed their teachers. On this basis and over two years, they designed pedagogic proposals, which they then implemented collaboratively with the classroom teachers. The team wrote reflection logs and produced a video describing the development of the project as part of the action research cycle. As illustration, one interdisciplinary team included a teacher of English with university student teachers of Philosophy, Chemistry and Biology; and another one involved an English teacher working with university student teachers of History, Geography and Philosophy and college students of Nutrition. The collaborative and interdisciplinary orientation to address citizenship themes in schools is at the forefront in theorisations of intercultural citizenship (Wagner, Conlon Perugini, \& Byram, 2018). With a narrower focus but similar interdisciplinary and collaborative basis and research design, Braun and Monserrat's (2017) action research involved university students in La Pampa attending the courses Intercultural Studies, English This is a peer-reviewed, author-accepted manuscript of the following research article: Porto, M., López-Barrios, M., \& Banegas, D. (2021). Research on English language teaching and learning in Argentina (2014-2018). Language Teaching, 1-33. 
Didactics and the practicum, who designed didactic sequences on the theme of identity and implemented them in local secondary schools together with their teachers and a British language assistant. Data gathered in the secondary schools comprised learner narratives in video and other formats, presentations on a variety of themes (the school, local festivals, the local national park), posters, photographs and a survey administered to the students. Findings showed that the experience proved motivating for the secondary school students as they became intercultural mediators and worked in collaboration to share their productions with the school community. The experience was also challenging for the student teachers as it involved a re-conceptualisation of teacher education based on intercultural citizenship premises. Both studies are in tune with recent developments in intercultural citizenship in world language education that foregrounds collaborative, interdisciplinary work carried out transversally in schools and universities to address socially relevant themes in an internationalist perspective and which connect with local communities beyond the classroom and the school (Byram, 2018; Byram \& Wagner, 2018; Wagner, Conlon Perugini, \& Byram, 2018).

Finally, Sergi (2017) analysed four General English coursebooks to investigate whether they catered for the development of intercultural communicative competence. Contrary to the expectation that standardised tests and materials do not usually focus on the skills associated with ICC, the author showed that these skills were in fact taken care of and concluded that the reason is that they are needed for life and work in current times.

Specifically, she found that the lead-in section of these textbooks included rich cultural elements, a focus on cultural values and Socratic questions to foster critical thinking. Raising awareness of the limitation that most of the cultural representations in this section of the coursebooks centred on British and American insights, the author pointed out the need for teachers to complement these textbooks with Socratic questions to develop criticality, This is a peer-reviewed, author-accepted manuscript of the following research article: Porto, M., López-Barrios, M., \& Banegas, D. (2021). Research on English language teaching and learning in Argentina (2014-2018). Language Teaching, 1-33. 
reflection and awareness in the advanced English language classroom.

Overall, while there are few studies designed on the basis of intercultural citizenship principles for world language education, they are solid, significant and anchored to the central tenets postulated by Byram and his colleagues. There is a need for the local academia to embrace this line of work more wholeheartedly because as Byram argues, it is not an approach but an educational philosophy that is inescapable. This philosophy is best realised through collaborative, interdisciplinary, internationalist, community-based and arts-based projects implemented transversally at all levels of education, including the education of future professionals of the language (Byram, 2018; Byram \& Wagner, 2018; Wagner, Conlon Perugini \& Byram, 2018). An area within intercultural citizenship that remains to be explored in the country is the social justice basis of language education (Osborn, 2008), nonexistent in the period reviewed.

\section{English language teacher education}

This section reviews those empirical studies which examine ELTE at both pre-service and inservice levels. In Argentina, initial and post-graduate ELTE programmes are offered by public and private universities and tertiary institutions (Amez \& Dobboletta, 2017). In line with international perspectives (Walsh \& Mann, 2019), ELTE is anchored in sociocultural and critical theories within education and is embraced as a process which combines general education knowledge, content knowledge, and pedagogical content knowledge. In line with insights from the global literature (e.g., Farrell, 2015; Walsh \& Mann, 2019), in Argentina it is agreed that that pedagogical content knowledge should be the cornerstone of all ELTE endeavours as the focus is on teaching English rather than studying the language as a system. Therefore, studies in ELTE emphasise informed teacher reflection, the practicum in preThis is a peer-reviewed, author-accepted manuscript of the following research article: Porto, M., López-Barrios, M., \& Banegas, D. (2021). Research on English language teaching and learning in Argentina (2014-2018). Language Teaching, 1-33. 
service ELTE, and professional practice. In this section, the term student-teacher refers to students completing initial/pre-service ELTE programmes. Studies in this section seem to cluster around these interconnected categories: (1) criticality, (2) teacher educators' practices, (3) identity, and (4) feedback. We consider them interconnected as teachers' and teacher educators' practices and perceptions run across them.

\subsection{Criticality}

According to Banegas and Villacañas de Castro (2016), criticality in ELT refers to the promotion of both critical pedagogies and critical thinking to empower learners and educators in their contexts and situated social practices. Under this broad term, the seven studies reviewed in this section are underpinned by criticality in ELTE. The studies show that critical pedagogies may be linked to post-method pedagogies in ELT (Kumaravadivelu, 2003). Postmethod pedagogies seek to help create ELT approaches and practices which respond to the particularities, practicalities and possibilities found in specific contexts by those who enact language teaching and learning processes.

Post-method pedagogies are usually the object of inquiry in pre-service ELTE and among experienced educators in Argentina. By means of a survey, Soto (2014) investigated a group of student-teachers' perceptions of post-method pedagogy in ELT. Findings showed that even when the student-teachers valued a prescriptivist approach to grammar teaching, they believed that local and context-responsive pedagogies should be incorporated in ELT through teacher-made materials. Moving beyond ELTE programmes, Tavella and Fernández (2017) carried out a survey among university ESP tutors to gain insights regarding their professional practices as manifested in course design, materials, and activities. The authors conclude that inadvertently, the tutors' practices have shifted and exhibit features of postmethod pedagogies as they have developed courses which include topics, input material, and

This is a peer-reviewed, author-accepted manuscript of the following research article: Porto, M., López-Barrios, M., \& Banegas, D. (2021). Research on English language teaching and learning in Argentina (2014-2018). Language Teaching, 1-33. 
activities that respond to the particularities and practicalities of the context in which they teach. The authors also noted higher levels of reflection and self-evaluation among the ESP tutors, and a sharper focus on learners' present and future professional needs.

At the intersection of critical pedagogy and critical thinking skills, four studies examined the development of higher-order thinking skills among student-teachers. Basabe and Germani (2014) examined the impact of critical pedagogy and critical literacy through discussions on literary texts with student-teachers. Drawing on data collected through focus groups, classroom observation, and interviews with the student-teachers, the authors concluded that there was an increase in team work among the student teachers and that they developed higher levels of reflection and confidence to discuss controversial topics such as non-binary sexualities. However, the student-teachers still exhibited a tendency to use description over evaluative comments to discuss a literary piece. Aware of the necessity of imbuing ELT with higher-order thinking skills, Sollier (2015) analysed student-teachers' writing of learning objectives in lesson plans. By conducting content analysis, the author reported that student-teachers showed a tendency to include lower-order thinking skills aims, and when they included aims to promote critical thinking, these were not anchored in activities which would scaffold higher-order thinking skills development. With a focus on helping student-teachers become aware of criticality, Caielli and Williams (2018) analysed a group of student-teachers' perceptions of their learners by means of critical discourse analysis (CDA). The authors analysed how student-teachers described learners from a vulnerable socio-economic context. They conclude that studies of this nature can help teacher educators guide student-teachers by making them aware of their linguistic choices when referring to learners and educational settings embedded in contexts under difficult circumstances. As part of a larger exploratory-interpretive research project on language teacher cognition (Borg, 2006), Regueira, Del Potro and Di Virgilio (2016) examined the perceptions of a group of

This is a peer-reviewed, author-accepted manuscript of the following research article: Porto, M., López-Barrios, M., \& Banegas, D. (2021). Research on English language teaching and learning in Argentina (2014-2018). Language Teaching, 1-33. 
student-teachers towards the use of English and L1 Spanish in their practicum experience. Results showed that through formative interaction with teacher educators and peers, the student-teachers developed a critical approach to language teaching, which allowed them to see the affordance of including learners' L1 (Spanish) as another tool for English language learning.

Critical thinking skills and critical issues can be developed and addressed among graduated teachers. Martino (2014) employed a qualitative research framework to study teachers' perceptions around gender and whether it may affect learning among primary school learners. The results indicated heterogeneous responses from teachers. While they indicated that a topic such as sports was more welcomed among boys, they acknowledged that choice of topics should be inclusive and gender-neutral. In secondary education, Valsecchi et al. (2016) utilised a sequential research strategy (survey followed by semistructured interviews) to gather EFL teachers' beliefs about different aspects of ELT in one Argentinian city. Results yielded teachers' particular interest in reflecting on the critical roles of culture, technology and writing skills in the EFL lesson. The authors believe that studies in the field of language teacher cognition can shed light on teacher education programmes and professional development opportunities to promote critical and informed reflections between external theories (content knowledge) and teachers' beliefs and personal theories drawn on personal trajectories as learners and teachers.

From a different angle but still connected to criticality in ELTE, Montserrat and Mórtola (2018) employed document analysis to examine the history and present of linguistic policies of foreign language teaching in Argentina. The authors argue that the hegemony of English as a foreign language in primary and secondary education has been favoured by central and regional policy makers in the country. Such policies, they show, have been enacted at the expense of other modern foreign and heritage languages in Argentina, and

This is a peer-reviewed, author-accepted manuscript of the following research article: Porto, M., López-Barrios, M., \& Banegas, D. (2021). Research on English language teaching and learning in Argentina (2014-2018). Language Teaching, 1-33. 
therefore, the so-called plurilingualism and linguistic diversity promoted in official documents is marginalised or simply absent in practice.

A common concern across these studies is the need to develop and implement context-responsive pedagogies that value local social practices and provide educators with pedagogical resources to enable learners to develop their critical thinking skills. In addition, the studies above illustrate that critical thinking and critical pedagogies in relation to potential topics and cognitive development in ELT should be considered among both student-teachers and experienced teachers regardless of the level of education they may teach. More importantly, these studies should be seen as a warning sign: ELT needs to engage in pedagogies that do more than superficial language learning. EFL should be seen as another opportunity in the curriculum for the development of critical citizenship, plurilingualism, and empowerment; this highly complex conceptual shift should start in initial teacher preparation.

\subsection{Identity}

With the exception of Mulone (2017), studies into teacher identity concentrated on studentteachers' trajectories employing narrative inquiry (Barkhuizen, 2020) within one academic year. Despite this difference, the studies reviewed in this section adopt a qualitative research paradigm to explore how the authors (researchers examining their own practice or interviewing present and past student-teachers) have made an imprint on (future) teachers' sense of professional identity.

Inscribed in narrative inquiry, Sarasa $(2014,2017)$ carried out small-scale studies with her own student-teachers at a pre-service ELTE teacher education programme to understand their trajectories while attending the author's module on communication. Through studentteachers' reflections materialised into narrative and poem writing, the author concluded that

This is a peer-reviewed, author-accepted manuscript of the following research article: Porto, M., López-Barrios, M., \& Banegas, D. (2021). Research on English language teaching and learning in Argentina (2014-2018). Language Teaching, 1-33. 
her own practices allowed the student-teachers to reflect on and develop their own present and future professional selves thanks to the autonomy and reflection dimensions featured in the module. Sarasa (2017) concludes that poems resituate narrative inquiry in teacher education not only as praxis but also as decolonising ontology and epistemology. In a similar vein, Sarasa and Solis (2017) explored the storied construction of future teachers' professional identity as expressed in multiple narratives and journal entries co-composed with ten student-teachers at a state university. The authors reported that the narratives coconstructed with their student-teachers permitted the understanding of student-teachers' renegotiation of present and future professional and personal identities through their universitybased trajectories.

De Laurentis (2015) reconstructed a narrative experience carried out with her studentteachers to explore the impact of culture as a tool to comprehend reality and narrativity as a natural form to organise experience in their identity construction. In this sense, the studentteachers developed awareness of their own perceptions of culture together with meta-analysis of narrative inquiry in their own development as future teachers. In turn, Mulone (2017) conducted research into EFL teachers' own professional identity after graduation. Data obtained from a survey and interviews revealed that as teachers gained experience and reflected on their lived experiences at university, they evolved from a limited and stereotyped perspective of EFL teacher identity to a more complex, broad, and realistic view. The participating teachers believed that their language teacher identity should not ignore wider educational imperatives and key issues and should also include social dimensions such as gender equality or wellbeing.

The five papers reviewed in this section share a similar concern: the centrality of ELTE programmes in teachers' personal and professional trajectories and how ELTE practices exert an enormous influence on becoming EFL teachers. However, the area of M., López-Barrios, M., \& Banegas, D. (2021). Research on English language teaching and learning in Argentina (2014-2018). Language Teaching, 1-33. 
teacher identity in ELTE could benefit from longitudinal studies which examine how specific aspects of ELTE programmes exercise their influence and enter into dialogue with external factors on (future) teachers' identity.

\subsection{Feedback}

Feedback is a dominant focus within the studies which examine ELTE, particularly in preservice programmes. The studies reviewed in this section reveal the authors' interest in understanding student-teachers' perceptions on feedback and characteristics of effective feedback and how it influences their performance in the practicum and academic writing.

Regarding feedback during the practicum experience, papers examined studentteachers' perceptions (Percara, 2015) and lesson plans (Rodríguez, Castro, García Álvarez, Scilipoti, \& Tacconi, 2015) and teacher educators' perceptions and post-observation feedback (Percara, 2015; San Martín, Faletti, \& Helale, 2016). The results from these four studies showed that while teacher educators valued and exhibited formative, guided, and indirect feedback to encourage student-teachers' reflection and self-discovery on lesson planning and delivery, student-teachers preferred direct formative feedback as it provided them with acute and expert information about their performance. Teacher educators' feedback was found to help student-teachers develop self-awareness of strengths and room for improvement and manage to identify potential courses of action.

In relation to feedback on academic writing, López Casoli and Berardo (2018) analysed student-teachers and teacher educators' perceptions of written feedback in essays and other genres which employ academic/formal English. Similar to the studies on feedback during the practicum, student-teachers and teacher educators held divergent views regarding the benefits of direct and indirect written feedback. While the former was preferred by student-teachers to improve accuracy, the latter was employed by teacher educators to raise

This is a peer-reviewed, author-accepted manuscript of the following research article: Porto, M., López-Barrios, M., \& Banegas, D. (2021). Research on English language teaching and learning in Argentina (2014-2018). Language Teaching, 1-33. 
student-teachers' language awareness and noticing.

While these papers adopted a qualitative perspective and focused on perceptions and practices, future studies should extend research on feedback to areas such as linguistic and textual accuracy in the case of academic writing and local knowledge generation in the case of feedback during the practicum experience.

\subsection{Teacher educators' practices}

While almost all the studies reviewed in the subsections above investigate aspects of teacher educators' practices or were conducted by teacher educators in their own modules, a few papers reported on teacher educators' interest in improving their own or others' overall practices. Such a focus seems to acknowledge the influential role that teacher educators' practices have in shaping future teachers' practice. It also recognises the need to investigate ways in which teacher educators' declarative knowledge of ELT methods and approaches are enacted in their own teaching.

Marconi (2016) analysed her own teacher educator's practices with a group of student-teachers at a university ELTE programme to find ways of improving her teaching and the student-teachers' overall experience. Through an interventionist model which combined her pedagogical and research interests, she designed lesson plans for a group of secondary school learners, which were reviewed by the student-teachers before implementation. Drawing on data collected by means of questionnaires, the experience allowed the studentteachers to become aware of aims, activity sequencing and pedagogical adaptations to suit different learners' needs.

Yuni and Díaz (2015) studied how three different tertiary ELTE programmes support their student-teachers to exercise their agency in making pedagogical decisions. Following a qualitative research approach, the authors carried out interviews and classroom observations

This is a peer-reviewed, author-accepted manuscript of the following research article: Porto, M., López-Barrios, M., \& Banegas, D. (2021). Research on English language teaching and learning in Argentina (2014-2018). Language Teaching, 1-33. 
with teacher educators. The authors found three dominating models of teacher educators' practices: transmission, co-construction, and eclecticism in which the teacher educators refrain from direct instruction.

Basabe (2016) studied the teaching of literature in an ELTE programme at a state university. To this effect, he interviewed teacher educators in charge of literature modules and found that even when the ELTE programme seeks to promote three literature teaching models, cultural, linguistic, and personal growth (Carter \& Long 1991), primacy is given to linguistic and cultural models.

As a preliminary conclusion, we may advance that Argentina can offer varied contributions in the field of pre-service ELTE at undergraduate level. With some exceptions, most of the papers reviewed above investigate the relationship between teacher educators, particularly those in charge of the practicum and ELT pedagogy modules, and studentteachers in relation to criticality, identity, feedback, and meaningful and formative practices which go beyond instrumental learning. As in the previous review on Argentina (Porto et al., 2016), these studies confirm teacher educators' interest in reflecting, revisiting, and enhancing their practices as they grow aware of the impact these have on student-teachers' professional development.

\section{Technology-enhanced language learning (TELL)}

TELL is currently viewed as an umbrella term to encompass different digital tools employed with clear language learning purposes (Walker \& White, 2013). TELL research gravitates on the inherently symbiotic and ubiquitous relationship between (language) pedagogy and information and communication technologies (Chapelle \& Sauro, 2017; Li, 2017). Between 2014 and 2019, TELL gained traction in a variety of contexts as the eight studies reviewed

This is a peer-reviewed, author-accepted manuscript of the following research article: Porto, M., López-Barrios, M., \& Banegas, D. (2021). Research on English language teaching and learning in Argentina (2014-2018). Language Teaching, 1-33. 
below show. Such an interest in research on TELL seems to be the consequence of educators who had implemented TELL in their practices and sought to measure the effects of such a change among their learners.

Two studies address teachers' beliefs and TELL practices in secondary education. Roccia and Sacchi (2015) reported a qualitative multiple-case study including interviews and lesson plan analysis in which they examined the belief of four EFL teachers about ICT in language learning. The four participants believed that technology integration was important in the EFL context. However, despite the fact that teachers held this belief, technology was not systematically included in the course curriculum. These beliefs are corroborated in a study carried out in another city within a similar setting. In a survey-based study Alcaráz (2015) collected data from 450 secondary school learners and 12 teachers from one city to analyse the use of netbooks provided by the government in the EFL class in state secondary education. The results indicated that netbooks were not systematically used in class, and only a limited number of participants reported their use to watch video segments for guided listening skills development.

In contrast, TELL seems to find more traction among ELTE and ESP tutors and learners. Studies focused in TELL in higher education showed researchers' interests in understanding tutors' and learners' use of information and communication technologies (ICT) and its impact on different areas of learning such as reading skills or intercultural awareness (Gava \& Anglada, 2015). Two studies looked at (self-) assessment of TELL among tutors' practices. According to these investigations (Innocentini \& Forte, 2016, Massa, Morchio \& Schander. 2016), tutors should create and evaluate their online materials and their multimedia-based activities against criteria which are the result of consensus between tutors and learners. Regarding learners, Castiñeira and Mucci (2014, 2017) and Orta González and Castro (2016) found that while virtual learning environments (VLEs) were used for M., López-Barrios, M., \& Banegas, D. (2021). Research on English language teaching and learning in Argentina (2014-2018). Language Teaching, 1-33. 
completing language learning skills, particularly reading and writing, they were also employed for interactional purposes among learners. These studies also concluded that social networks (e.g., Facebook) or self-managed websites (e.g., blogs) and shared folders embedded in VLEs were a powerful tool for strengthening writing skills development, highlighting learners' personal and interpersonal skills within a collaborative environment, and for developing critical and creative thinking skills.

What the reports summarised above show is that even when VLEs and blended learning approaches are employed, TELL is always used as an add-on to face-to-face language learning. However, studies found in international outlets (e.g., Banegas \& Manzur, 2014) reported the use of TELL for entirely online ELTE programmes in the country. Concerning research methods, the papers employed exploratory and action research frameworks to collect data, particularly using interviews, reflective journals, and surveys. While these endeavours contribute to our understanding of TELL, future studies should gather data over longer periods of time and provide in-depth data analysis and discussion.

\section{Learner differences in English language learning}

A multiplicity of learner internal and external factors influences the complex process of foreign language learning (Lightbown \& Spada, 2006; Ellis, 2008; Mahmoudi \& Mahmoudi, 2015). Based on our analysis, the papers reported in this section cluster around three sets of individual differences pertaining to cognitive and affective factors: strategies and learner autonomy, beliefs and attitudes, and affectivity. These three individual differences exhibit authors' interests in understanding and improving connections between affective factors and academic performance.

This is a peer-reviewed, author-accepted manuscript of the following research article: Porto, M., López-Barrios, M., \& Banegas, D. (2021). Research on English language teaching and learning in Argentina (2014-2018). Language Teaching, 1-33. 


\subsection{Strategies and learner autonomy}

Another set of six studies focuses on vocabulary learning strategies which contribute to learner autonomy $(\mathrm{Gu}, 2020)$. The studies are discussed below according to the research methods employed.

With the aim of exploring vocabulary learning strategies among different learners, three research projects used surveys, thus becoming studies based on self-reporting. For example, for comparative purposes, learners from state secondary schools and a universitybased secondary school (San Martín \& Helale, 2017), and teenage learners from a bilingual school and a language school (Alcázar \& Altamirano, 2017) completed surveys to indicate their preferred strategies for vocabulary learning. In both cases, no significant differences were found as all the learners exhibited a limited number of strategies for vocabulary retention in particular. In another study based on self-reporting, Insirillo and Ortiz (2018) identified the frequency of use and the variety of strategies employed by higher education learners attending an ESP course. Results revealed a scarce number of highly used vocabulary strategies. While these studies provide helpful hints with direct pedagogical implications, there should be further efforts for data triangulation and evidence of learners' actual behaviour.

Closer to experimental designs, three studies dealt with the direct instruction of specific vocabulary learning strategies with higher education learners. Gava, Dalla Costa, and Kofman (2016) provided explicit instruction of strategies for learning collocations and idiomatic expressions. Drawing on surveys, pre- and post-tests, the authors concluded that learners developed autonomy to understand and use collocations and idiomatic expressions. In a similar vein, González de Gatti and Sánchez (2016) provided a group of student-teachers with direct instruction of affixes as a strategy for solving gap-filling exercises. According to the data gathered by means of pre- and post-tests, it was observed that the student-teachers

This is a peer-reviewed, author-accepted manuscript of the following research article: Porto, M., López-Barrios, M., \& Banegas, D. (2021). Research on English language teaching and learning in Argentina (2014-2018). Language Teaching, 1-33. 
improved their performance at the levels of word formation and reading comprehension skills. Another study (González de Gatti, Orta González, \& Sánchez, 2016) focused on strategies for vocabulary retention included an experimental group and a control group. The experimental group received explicit instruction in the use of concordancers to find examples of words belonging to the same semantic field. Through pre- and post-tests the authors concluded that the experimental group outperformed the control group in activities which required learners to employ words sharing the same semantic field. Also through the inclusion of control and experimental groups, Valenti and Galimberti (2015) carried out a longitudinal study to analyse the effect of the development of metacognitive strategies sometimes aided with ICT on ESP students' efficiency and autonomy. The authors established a correlation between the development of metacognitive strategies and a better performance as the students of the experimental group outperformed those of the control group in the first stage of this research work. The experimental group also revealed a higher degree of accuracy accompanied by a higher degree of explicitness by the end of the academic year.

While in the previous review (Porto et al., 2016) papers featured research on learning strategies for language skills development, grammar, and lexis, the papers between 2014 and 2019 not only focused on vocabulary learning but also signalled that interest in learning strategies was mostly circumscribed to one large group of researchers established at one specific university. We hope that researchers engage in longitudinal studies to measure the sustainability of their practices and learners' (perceived) performance.

\subsection{Beliefs and attitudes}

In this section, three studies related to learners' beliefs and attitudes are reported. The two

This is a peer-reviewed, author-accepted manuscript of the following research article: Porto, M., López-Barrios, M., \& Banegas, D. (2021). Research on English language teaching and learning in Argentina (2014-2018). Language Teaching, 1-33. 
first studies in this area refer to secondary school learners, the last one to university students. Barbeito, Placci, Ponce and Galfioni (2016) set out to find out about pupils' beliefs regarding learning English in the secondary school context. A total of 1,600 fifth-year (16-17 year olds) learners of state and private schools completed a questionnaire consisting of Likert scale and open questions related to the role of grammar, motivation, learning strategies, materials and use of technology, time devoted to English teaching, use of the target language in class, and discipline. Findings indicate that learners prefer both a deductive and an inductive approach to grammar teaching, that they attribute a key role to grammar in the learning process and state the importance of appealing content topics. Additionally, learners expressed they would use learning strategies if they were taught, that they expect teachers to cover most of the coursebook contents and to use other materials, that more class hours would be necessary, and that teachers make little use of the L2 in class. Interestingly, a vast majority of learners stated that they would invest more effort if the activities interested them. Reactions related to the use of technology showed inconclusive results, so that authors found this aspect should be further explored. In the other study, San Martín, Altamirano, and Villanueva de Debat (2016) examined the vocabulary learning beliefs and perceptions of adult and teenage learners in two educational settings: formal (schools) and non-formal education (language schools). The first involved 81 beginning EFL learners from three different institutions, whereas the second included 29 adult learners. The study aimed at finding similarities and/or differences between the two. Data was gathered through a structured questionnaire tapping into the learners' vocabulary learning strategies, their beliefs about vocabulary learning and the perception of their own vocabulary learning. Irrespective of the age and learning context, results revealed many similarities in both groups, what led authors to consider the social construction of beliefs, for example, the consideration of the role of aptitude in vocabulary learning, as an influential factor. Results of this study could have an impact on teachers' vocabulary teaching This is a peer-reviewed, author-accepted manuscript of the following research article: Porto, M., López-Barrios, M., \& Banegas, D. (2021). Research on English language teaching and learning in Argentina (2014-2018). Language Teaching, 1-33. 
practices, e.g. by reflecting on the way learners view their vocabulary learning process.

Piquer, Ponce, and Padula (2017) focused on the development of beliefs about the relationship between language and culture in the context of a plurilingual and pluricultural pre-bachelor degree course at a state university. The research aimed at finding out how these beliefs evolved as a group of nine students advance in their study of English and French. To this end, two open-ended questionnaires were implemented, one at the beginning of the first academic year and another at the end of the second year. A content analysis of the data indicated that subjects' initial beliefs conceived culture as the customs of native speakers, and that the target culture became explicit in class through the experiences of visitors to the L2 countries. Responses to the second questionnaire revealed that students now consider both the home and the target cultures, albeit separately. Results suggest that the intercultural approach followed in class had a degree of impact on the initial beliefs, but the causes of the stability of deeply ingrained beliefs should be the object of further investigation.

The previous review by Porto et al. (20016) expressed the need to involve larger populations in the study of beliefs and attitudes. This is now noticeable in the study by Barbeito et al. (2016) which involved 1600 pupils in both public and private secondary schools, and in San Martín, Altamirano and Villanueva's (2016) study of 130 learners in different types of secondary schools as well as in adult education. The geographical distribution of these studies is still the same as in the previous review, so that, again, studies tapping into beliefs and attitudes of learners in other locations and different sociocultural settings would be welcome.

\subsection{Motivation, preferences and emotions}

There are three studies under this topic which addressed the age factor and the affective

This is a peer-reviewed, author-accepted manuscript of the following research article: Porto, M., López-Barrios, M., \& Banegas, D. (2021). Research on English language teaching and learning in Argentina (2014-2018). Language Teaching, 1-33. 
dimension. We begin with González (2018), Fernández, Marchegiani, Picelille and Raspa (2015) and Fernández and Raspa (2016), who studied a population usually under-represented locally, namely senior learners in university settings. González (2018) explored the motivations to study English and related affective factors of a group of 60 adult learners taking part in a university program for adult learning in different disciplines in an exploratory study in the city of Buenos Aires using a questionnaire. Findings showed that a desire for personal growth and a pleasurable setting for learning were significant aspects for this age group. Focusing on university students in their mid and late adulthood (40-65 years of age) learning English as part of their Law and Political Sciences programmes at UNLaM, Fernández et al. (2015) set out to study their learning styles, preferences and motivations as well as the profile and role of the English teacher of this population. Undertaken in 20132014 and using a mixed methods design with questionnaires, 80 adult students and 40 crosscurricular teachers of English participated and findings showed that these adult learners were autonomous, committed to their process of continuing education or lifelong learning, and their affective filter tended to be high. In other words, negative emotional and motivational factors such as anxiety, alienation, embarrassment or self-consciousness, among others, interfered with the reception and processing of comprehensible input. Consequently, teachers needed to take on an important role as facilitators. In a subsequent study, Fernández and Raspa (2016) explored in greater depth the learning preferences of 30 adult students in the same context. They implemented a lesson which consisted of different tasks that catered for each of Gardner's (1983) Multiple Intelligences. After reading the short story Dad's Blessing, students were asked to visualise it, reflect on it in writing, retell it orally, debate a theme, conceptualise it using mind maps or similar formats, collaboratively write a dialogue among the characters, read aloud a scene and act it out, and do inferencing tasks. These student outcomes became the data types, followed by a questionnaire. Findings revealed the diversity M., López-Barrios, M., \& Banegas, D. (2021). Research on English language teaching and learning in Argentina (2014-2018). Language Teaching, 1-33. 
of student preferences in this age group, pointing to the need to offer classroom tasks centred not only on verbal-linguistic intelligence but also on the intrapersonal, interpersonal and logical-mathematical intelligences.

In a totally different context, Soto and Waigandt (2018) investigated the academic emotions that affect learner performance in oral presentations in a higher education setting. Participants in their exploratory study were ESP undergraduates at Bioengineering and Bioinformatics programmes, who performed oral presentations in pairs or small groups and completed a self-report instrument. Students completed an online questionnaire drawn from the Academic Emotions Questionnaire developed by Pekrun et al. (2002), which comprised 26 questions exploring students' emotions before, during and after giving their oral presentations. Findings showed that the achievement and epistemic emotions prevailed, with some social emotions also arising. The researchers explored implications, mainly related to the need to foster learner awareness about the fact that emotions can be consciously managed, controlled, shaped, and transformed as well as teacher awareness of the need to teach strategies to this aim.

In sum, while research in this area is very scarce, it addresses significant topics which resonate with the global research agenda and comprise age factors, particularly the needs and affects of adult learners ranging from 40 to 65 , and the role of emotions in world language education (Bigelow, 2019; Dewaele, 2018), including academic environments.

Comparing the number of papers of the 2007-2013 review (Porto et al., 2016) with this one, little has changed in the area of learner differences: the same number of papers are found in strategies and learner autonomy (seven) and in beliefs and attitudes (three), and there is a minor difference in motivation, preferences and emotions (three and four). By the nature of this line of inquiry, more case studies would be welcome to observe the extent to

This is a peer-reviewed, author-accepted manuscript of the following research article: Porto, M., López-Barrios, M., \& Banegas, D. (2021). Research on English language teaching and learning in Argentina (2014-2018). Language Teaching, 1-33. 
which contextual factors found in other geographical and cultural settings exhibit similarities and differences with trends observed in Argentina.

\section{Skills development}

Research classified under this topic comprises the four skills. However, the majority of the selected papers concentrate on writing, reflecting the interest of local researchers in this area as a tangible measure of learners' L2 development. Unlike research on reading (See sections 7.1 and 9.1), studies on listening and speaking are scarce, represented by only one paper in each category, indicating an area in which more work is needed. Despite these differences in focus, the papers included in the following two sub-sections exhibit that skills development overlap with other of the categories such as TELL or feedback reviewed in this article. In this regard, the studies illustrate that in terms of research and practice, skills development may act as a space in which other areas are subsumed in a dialogic manner.

\subsection{Reading, listening and speaking}

Reading researchers are interested in discovering the factors that impinge on reading locally with the ultimate aim of improving the reading performance of their students. Vázquez and González (2015) examined the extent to which the redundancy effect influenced the L2 reading comprehension skills of two groups of learners whose ages and English language proficiency differed widely. There were 59 participants, of whom 24 were teenagers with low-intermediate proficiency and 35 were advanced EFL majors. Each group was divided into two sets. One was exposed to a single mode of instruction (reading alone) while the other was presented with a dual format (reading and listening simultaneously). Results revealed This is a peer-reviewed, author-accepted manuscript of the following research article: Porto, M., López-Barrios, M., \& Banegas, D. (2021). Research on English language teaching and learning in Argentina (2014-2018). Language Teaching, 1-33. 
that students presented with the single mode of instruction outperformed the other group in the reading comprehension task, independently of their command of the language.

Furthermore, when comparing results obtained in both read-only groups (low-intermediate and advanced), the students with higher proficiency obtained better results. In the light of the findings revealed, some pedagogical implications for reading comprehension instruction were discussed.

Regarding listening, in an action research project, Spataro (2015) explored how five listening sessions were designed on Moodle 2.3 based on the review of possible activities that aid perception skills and the ways in which ICTs have been used to design online listening activities. The premise was that ICTs can foster listening comprehension. Participants were 15 voluntary intermediate EFL majors. Data were collected from students' records of the online activities, personal journals after each session, a final questionnaire and pre and post IELTS (International English Language Testing Scheme) listening tests. The analysis aimed to evaluate and reflect upon the effects of the action. Findings showed that the self-access perception activities designed with different ICT tools were successful. Comparison of the average marks of the pre- and post-tests showed that there was a slight improvement in performance. On this basis, the researcher pointed to the need for a process approach to L2 listening in which the listening components are targeted systematically and progressively.

Turning to speaking, in a multi-case study, Laucirica (2016) investigated the impact of two-month direct teaching and practice of communicative strategies in a levelling language course for newcomers to an ELTE programme, which was later replicated with $4^{\text {th }}$ year ELTE at tertiary level. In both cases, the corpus comprised recorded oral productions and class observations. Findings showed gains in fluency and confidence but no gains in declarative knowledge. It should be noted that the teaching and practice centred on formulaic phrases (see Pérez \& Zinkgraf, 2017; Rodeghiero, 2017; Valcarce \& Fernández, 2017, who studied This is a peer-reviewed, author-accepted manuscript of the following research article: Porto, M., López-Barrios, M., \& Banegas, D. (2021). Research on English language teaching and learning in Argentina (2014-2018). Language Teaching, 1-33. 
formulaic phrases in writing) and explicitly encouraged students to interact on the basis of the values of respect, cooperation, kindness and solidarity, which are the values upon which intercultural citizenship education builds. In this sense, the study addressed the challenges of language education to contribute to the development of democratic societies and the evolution of individuals and societies - a goal of education (Council of Europe 2018; Organisation of American States 1994-2018; Organisation of American States 2011; UNESCO 2015).

\subsection{Writing}

Here research can be classified into the following themes: genre-related issues (Calvo \& Ríus, 2017; Cangialosi, 2016; Ginevra, 2014; López Casoli \& Selesán, 2016; López Casoli \& Borgnia, 2018; Oliva \& de Maussion, 2017), contrastive rhetorics (Pico \& Sleibe Rahe de Paradelo, 2017), student writing using digital technologies (Dalla Costa \& Gava, 2016, 2017; Gava \& Dalla Costa, 2018), note taking (Vázquez \& González, 2018), feedback (López Casoli \& Berardo, 2017; Machado \& Lucas, 2017; Machado, Lucas \& Berardo, 2017) and formulaic sequences (Pérez \& Zinkgraf, 2017; Rodeghiero, 2017; Valcarce \& Fernández, 2017).

Beginning with genre-related topics, in a descriptive study underpinned by systemic functional linguistics and genre pedagogy, Ginevra (2014) explored the difficulties college students experienced in the writing of argumentations in English. The corpus was formed by 38 argumentative texts produced by future teachers and translators of English in their $3^{\text {rd }}$ year at Universidad del Aconcagua. The texts were divided in clauses and were analysed quantitatively in terms of projection and expansion relations. The lexico-grammatical features of four elements of the genre were analysed, namely theoretical frame, thesis, arguments, and

This is a peer-reviewed, author-accepted manuscript of the following research article: Porto, M., López-Barrios, M., \& Banegas, D. (2021). Research on English language teaching and learning in Argentina (2014-2018). Language Teaching, 1-33. 
thesis re-instantiation. Findings showed that even though the texts displayed these elements in different degrees, they were in fact used as a macrostructure with little or poor content. In other words, the students were not able to manipulate the discursive resources to reflect upon the material and symbolic objects proposed to them. Similar difficulties were observed by Cangialosi (2016), who explored interruptions in the flow of information in students' writings that affected communication. Participants were $102^{\text {nd }}$ year ELTE student-teachers who wrote an article on one specific topic. The researcher undertook three levels of analysis, namely macrotheme-macronew (text level); hypertheme-hypernew (paragraph level); and themerheme (clause level). Findings showed that even though most compositions presented many problems at the level of organisation of information, students attempted to keep a thematic progression as well as a line of development, either through comparison or parallelism in each paragraph of their compositions. As mentioned before, these difficulties at the level of organisation and macrostructure were also pinpointed by reading researchers (González, Otero \& Rocca, 2014) and in this sense, the importance of selective feedback (see Machado, Lucas \& Berardo 2017 reported later) is to be highlighted.

Framed within systemic functional linguistics (Halliday, 1978, 2004; Halliday \& Hasan, 1976) and genre theories (Martin \& Rose, 2008, 2012), Calvo and Ríus (2017) and Oliva and de Maussion (2017) studied texts (description of places) produced by new university students enrolled in university English programmes before (25 texts) and after (25 texts) explicit teaching of the genre description. Calvo and Ríus (2017) focused on the use of cohesive devices (reference, ellipsis, substitution and lexical cohesion) and their findings showed that writing performance improved very slightly after the explicit teaching of specific genre conventions. Specifically, the students used cohesive devices more frequently and they displayed a greater variety of devices but sometimes this use was incorrect. In turn, with the same corpus, Oliva de Maussion (2017) analysed the use of verb processes, forms and tenses This is a peer-reviewed, author-accepted manuscript of the following research article: Porto, M., López-Barrios, M., \& Banegas, D. (2021). Research on English language teaching and learning in Argentina (2014-2018). Language Teaching, 1-33. 
to discover only very modest improvements mainly in verb forms and tenses. In both cases, the researchers concluded that more nuanced and sustained instruction might have been necessary. López Casoli and Selesán (2016) studied the use of connectors with ELTE. They compared connector usage in two different types of texts within the exposition genre (compare-contrast and cause-effect). They departed from the fact that while previous studies had shown that the frequency and types of connectors used varied according to text type, the degree of incidence of how appropriately they were used had not received enough attention. In particular, the researchers analysed whether the type of text that students wrote influenced the type, quantity and quality of the connectors used. Results showed that genre influenced the appropriateness and type of connectors used. The authors also discussed the pedagogical implications for writing instructors when teaching and evaluating students' written performance. Finally, López Casoli and Borgnia (2018) aim to find out the types of connectives used in two sorts of academic texts (narrative and cause and effect) by ELTE students. The study centres around the influence of the text type on the amount and type of connectives used and on their suitability. For this, a corpus consisting of both types of texts written as a home assignment was compiled. A similar number of samples was obtained (41 narrative, 32 cause-effect) and their average length was found to be similar. The quantitative analysis indicates that writers used twice as many connectives in cause-effect than in narrative essays, that connectives of result/inference were the most frequent for both kinds of texts, and that cause/effect essays displayed the greatest variety of connectives used. Results confirm the hypothesis that the kind of essay may determine the quantity and type of connectives used. Authors warn that the results may be constrained by the topic of the essays. A high incidence of erroneous use of connectives was also found in the corpus so that the findings point to the need of associating text types and their typical connectives.

Within contrastive rhetoric, Pico and Sleibe Rahe de Paradelo (2017) carried out an This is a peer-reviewed, author-accepted manuscript of the following research article: Porto, M., López-Barrios, M., \& Banegas, D. (2021). Research on English language teaching and learning in Argentina (2014-2018). Language Teaching, 1-33. 
action-research with 17 advanced language students in English programmes. Data comprised interviews and argumentative texts produced by the students before and after explicit instruction. There were three stages. The first one focused on the analysis of differences between expository and argumentative texts in L1; the second one on awareness of the similarities and differences between argumentative texts in L1 and L2; and the third on the testing of the hypothesis that was the point of departure of the study: awareness of contrastive rhetorics improves the writing performance of argumentative texts in L2. Findings showed that explicit instruction in contrastive rhetorics significantly improved argumentative writing in L2 mainly at the macrostructural level, with increased metalinguistic awareness but little improvement in the appropriation of the grammatical features of the genre, the implication being that more contextualised grammatical instruction is needed in this setting.

Gava and Dalla Costa (2018) and Dalla Costa and Gava (2016, 2017) have been investigating college student writing using digital technologies for a number of years. In a quasi-experimental, mixed methods study using questionnaires, surveys and essay writing assignments, they researched the impact of an online discussion forum (ODF) as a prewriting activity on the productions and perceptions of 32 ELTE students enrolled in an English language course in their $2^{\text {nd }}$ year at a national university. Their findings showed that the cognitive and social opportunities afforded by ICTs favoured the collaborative construction of knowledge through online dialogue and the application of higher order thinking skills, which became evident in the students' contributions to the ODF, their opinions about the online activity, and their productions in the writing task.

Considering that systematic note taking instruction seemed to be almost non-existing, Vázquez and González (2018) proposed a framework for direct note-taking instruction and analysed its impact on the recall of information when listening to lectures in a foreign language, taking into account the quality of the recalled ideas (main and secondary). This is a peer-reviewed, author-accepted manuscript of the following research article: Porto, M., López-Barrios, M., \& Banegas, D. (2021). Research on English language teaching and learning in Argentina (2014-2018). Language Teaching, 1-33. 
Participants were 38 secondary school students in their $4^{\text {th }}$ year with a pre-intermediate level of English, who completed a pre-questionnaire about their experiences with note taking. Then they took a pre-test, in which they listened to a short lecture, took notes and wrote a freerecall task without access to their notes. Four lessons on note taking instruction followed and students took a post-test resembling the pre-test. For analysis, the researchers quantified the idea units, main and secondary, in the lectures and in the recalled texts by the students, and compared results. Findings showed that students remembered both more main and secondary ideas after receiving instruction on note taking.

Focusing on feedback, Machado, Lucas and Berardo (2017) studied the influence of different kinds of feedback on writing with $1^{\text {st }}$ year ELTE with different levels of linguistic competence. In a first quantitative investigation, their aim was to shed light on how students interpreted teacher feedback and elaborated on it to then examine if this feedback contributed to the rewriting process. The corpus comprised a set of 376 sentences taken from a mid-term exam, corrected by the teacher some time before, accompanied by the identification of the errors and an improved version provided by the participants. Findings were moderate as only half the students were able to identify their errors and correct them. On a second qualitative stage, the researchers compared comprehensive feedback (i.e. the teacher corrected all errors) and selective feedback (the teacher focused on a selection of errors, in this case, ideas, cohesion and coherence). Students produced an essay and were divided into two groups, each of which received either kind of feedback. Findings showed that the students who received comprehensive feedback felt overwhelmed and self-corrected only some of the errors marked by the teacher, usually the less demanding and form-focused errors, leaving content and coherence unedited. Those who received selective feedback produced better organised second drafts. A post survey revealed that students valued selective feedback as they expressed they had more difficulties with content, cohesion and coherence. It should be noted This is a peer-reviewed, author-accepted manuscript of the following research article: Porto, M., López-Barrios, M., \& Banegas, D. (2021). Research on English language teaching and learning in Argentina (2014-2018). Language Teaching, 1-33. 
that this finding aligns with the research on reading (González, Otero and Rocca, 2014) and writing (Cangialosi, 2016; Ginevra, 2014) reported earlier, which also pointed out these difficulties. Machado, Lucas and Berardo's (2017) contribution resides in their highlighting of the importance of providing selective feedback - a recommendation that can be complemented by Pico and Sleibe Rahe de Paradelo's (2017) finding reported before concerning the usefulness of explicit instruction in contrastive rhetorics to improve L2 writing at the macrostructural level.

López Casoli and Berardo (2017) analysed written indirect teacher feedback, in particular questions intended to guide students, taken from 36 narrative pieces produced by advanced ELTE students. The effectiveness of such feedback was investigated by examining the students' error self-correction on their second drafts, among other dimensions. Findings showed that students addressed $64 \%$ of the teacher questions with $84 \%$ accuracy. Two teachers were surveyed and expressed they valued indirect feedback of this kind. The researchers highlighted that feedback, in order to be effective, had to be unambiguous and moderate in quantity as students tended to feel overwhelmed when there were too many questions or these were unclear, in which case they opted for not editing those sections. In the same context and with the same participants and corpus, Machado and Lucas (2017) analysed the impact of indirect teacher feedback, this time focusing on commentaries, imperatives, statements, exclamations, metalanguage, symbols and combined comments. Findings showed that the most effective forms were imperatives, statements, commentaries and metalanguage while exclamations and symbols were less effective, in general left unedited by students.

In another line of research, Valcarce and Fernández (2017), Rodeghiero (2017) and Pérez and Zinkgraf (2017) studied formulaic sequences (FSs) as these play a pivotal role in language learning and teaching because they enable L2 learners to use the language fluently This is a peer-reviewed, author-accepted manuscript of the following research article: Porto, M., López-Barrios, M., \& Banegas, D. (2021). Research on English language teaching and learning in Argentina (2014-2018). Language Teaching, 1-33. 
and productively. They used biographies from a vocabulary-focused perspective. Valcarce and Fernández (2017) investigated which FSs a group of $791^{\text {st }}$ year students of the Teacher and Translation Training Courses mastered and how accurately they employed them with the aim of identifying their language needs in relation to formulaicity and biography writing. Using corpus analysis, findings showed that students produced non-native combinations, which suggests that their formulaic competence was underway but also that as language learners, they were equipped with compensation strategies, which they employed when they were urged to convey meaning and their formulaic knowledge was limited. In a case study in a state secondary school context, Rodeghiero (2017) explored the effects of explicit instruction of two FSs, at the age of and from an early age, on biography writing with 24 students attending their $3^{\text {rd }}$ year. The study employed a quasi experimental design with a pretest, an intervention with form-focused instruction, and a post-test. Both tests involved the writing of a biography on the same theme. Results showed that, even at a beginner level and in a foreign language context with very limited exposure to the L2, explicit instruction was beneficial for these particular students' learning of FSs as observed in the post-test biographies. The researcher concluded that further research is necessary to examine the effects of FSs explicit instruction on the acquisition of more target FSs, differing in factors such as frequency or register or over time, and in more spontaneous written and oral production, with a larger number of participants. As this report shows, only one study reviewed here (Laucirica, 2016) focused on explicit instruction of FSs to improve oral skills and this area is clearly under-researched. Finally, Pérez and Zinkgraf (2017) characterised advanced EFL university learners' use of FSs lexically expressing a cause-effect relation in the writing of essays. The students were in either the EFL Teacher-Training or Translation programmes taught at Comahue University. Of all those who took the annual subject English IV between the years 2008 and 2014, 237 learners gave their written consent for their first M., López-Barrios, M., \& Banegas, D. (2021). Research on English language teaching and learning in Argentina (2014-2018). Language Teaching, 1-33. 
written essay to be included in the corpus. Using comparative corpus analysis (native and learner corpora) in relation to the nouns EFFECT, IMPACT and INFLUENCE as appearing in the corpus of written essays, learners seemed to be sensitive to native speaker preferences as shown in the relative frequency of the FSs involving these three nouns. However, closer analysis of the concordance lines obtained shed light on different degrees of unawareness as regards collocates (verbs accompanying the nouns) and the typical modality and aspect that modify these FSs. The researchers concluded that there was still a wide distance for learners to cover on their way towards native-like choices and recommended continuous, cyclical and recurrent exposure to target forms in order to reach higher levels of proficiency in terms of formulaicity and naturalness.

Overall, research on skills shows that research on listening and speaking is almost non-existent in Argentina and research on reading is scarce. There is however a strong, varied and well-developed body of work on the writing skill, studied in different contexts and consistent with the variety and breadth of current research in this area in other parts of the world. The investigation of reading and writing in digital environments (Warschauer, Zheng \& Park, 2013), an area that was poorly investigated a few years ago (see Porto et al, 2016), is now beginning to gain momentum. However, one limitation that we mentioned in our previous review article (Porto et al., 2016) is observed here too, namely the lack of research in specific areas such as the cultural dimension of reading (Porto \& Byram, 2017) and the connection between reading and writing (Warschauer, Zheng \& Park, 2013).

\section{English language systems}

This section includes studies related to the acquisition of morphosyntax, lexis and phonology, with some following a descriptive approach and others an experimental one. A common This is a peer-reviewed, author-accepted manuscript of the following research article: Porto, M., López-Barrios, M., \& Banegas, D. (2021). Research on English language teaching and learning in Argentina (2014-2018). Language Teaching, 1-33. 
interest across the papers included in sub-sections below is authors' interests in developing teaching strategies that support learner's language awareness enhancement in terms of fluency and accuracy.

\subsection{Vocabulary}

Papers in this section have two main research foci: descriptive and experimental. The first concentrate on the characteristics of the vocabulary dealt with in class (Sapag \& Boldrini, 2017) or used by the learners in their production (Zinkgraf, Rodríguez, Castro \& Verdú, 2015, Zinkgraf \& Verdú, 2015; Grundnig \& Himelfarb, 2017). The experimental studies test the effectiveness of teaching procedures on students' lexical development (Zinkgraf \& Verdú 2017; González de Gatti, Sánchez \& Orta 2017).

Sapag and Boldrini (2017) looked into the authenticity of the vocabulary content of elementary level EFL lessons observed in secondary school and language school contexts. In these lessons, less than a third of the vocabulary was taught at the learners' request, indicating that a part of the words treated in class purposefully responded to a need from learners to express personal meanings or fill an individually motivated comprehension gap. Moreover, authors found that most of the learner selected words were relevant to the topic and activity dealt with. In this sense, they contend that the vocabulary is authenticated by the learners because it fulfils a relevant and meaningful productive or receptive communicative purpose.

Zinkgraf et al. (2015) studied the use of discourse-organising formulaic sequences (FS) by advanced EFL majors. To this end, authors analysed a corpus of 237 academic essays from several cohorts of the programme in search of the formulaic sequences used to organise learners' discourse and compared it to native speaker occurrences in the British National

This is a peer-reviewed, author-accepted manuscript of the following research article: Porto, M., López-Barrios, M., \& Banegas, D. (2021). Research on English language teaching and learning in Argentina (2014-2018). Language Teaching, 1-33. 
Corpus (BNC). Findings showed that students' pattern of use and frequency rate of some FS such as "as a result" or "on the other hand" coincided with those found in the BNC, whereas other constructions deviated from the instances contained in that corpus. Moreover, authors found learners seemed to prefer connectors as discourse-organisers rather than linking FS. The findings are relevant for the implementation of teaching procedures aiming at learner awareness with regard to more target-like vocabulary use. The same learner corpus was used by Zinkgraf and Verdú (2015) to study the frequency of use of FS with the word "fact" by both advanced EFL learners and competent users of English. Findings revealed a degree of overuse of certain FS compared to expert use, and the presence of non-target like FS.

In a similar vein, Grundnig and Himelfarb (2017) developed a vocabulary teaching procedure aimed at undergraduate students of Tourism at a national university. The proposal drew on two corpora studies, one of vocabulary in research article abstracts from the field of tourism, and one of the lexical use of students in oral presentations. The first analysis revealed the proportion of general, academic and technical vocabulary which served as a basis for the analysis of the learner corpus. In this way, authors could compare the students' lexical performance with the lexical content of the abstracts in order to determine the students' frequency and quality of use of tourism vocabulary. Findings from the learner corpus indicated high use of general vocabulary and low use of academic vocabulary, whereas the proportion of technical vocabulary was similar to that found in the abstracts. A lexical error analysis of the learner corpus also allowed insights into the difficulties learners experience with vocabulary. These involve the incorrect selection of a word (e.g. "results" instead of "resources") or of a member of a lexical combination (e.g. *put in question). These kinds of studies are infrequent in the national context and should be extended to more areas, as work in the description of learner corpora could have important pedagogic implications.

This is a peer-reviewed, author-accepted manuscript of the following research article: Porto, M., López-Barrios, M., \& Banegas, D. (2021). Research on English language teaching and learning in Argentina (2014-2018). Language Teaching, 1-33. 
Zinkgraf and Verdú (2017) reported on an experimental study in which 13 advanced ELTE students were explicitly taught a series of formulaic sequences (FS) extracted from course materials to assess the impact of instruction on their production of target-like samples of the FS in both controlled and spontaneous use. Results indicated that, in controlled use, learners occasionally resorted to variations of the FS, whereas in spontaneous use some subjects correctly produced the form of the FS, but failed to employ them to express the intended meaning or in an unsuitable context. In their study, González de Gatti, Sánchez and Orta (2017) set out to test the effectiveness of instructing advanced ELTE students in the use of a vocabulary learning strategy (VLS) consisting in keeping a record of word information related to synforms, i.e. words with similar formal characteristics but with different meaning, as in affect/effect. Two intact class groups were selected for the experiment. After receiving instruction of the VLS, the control group was asked to concentrate on the meaning and use of the synforms, whereas the experimental group was asked to keep a vocabulary notebook where they were to record a predefined number of lexical features proposed by Laufer (1997, in González de Gatti et al., 2017). Results indicated a better performance of the experimental group, thus demonstrating the effectiveness of the procedure.

\subsection{Phonology and grammar}

This section analyses papers related to the acquisition of phonology and grammar. The four studies related to the acquisition of pronunciation followed an experimental design. The two first ones set out to test how non-native speakers (NNS) of English of limited proficiency perceived segmental and suprasegmental features in the speech of a native speaker (NS) (Panzachi Heredia, 2017) and of a fluent NNS (Vázquez \& González, 2016). The two next studies (Perticone 2017, Castellano, Garay, \& García, 2015) concentrated on learners' This is a peer-reviewed, author-accepted manuscript of the following research article: Porto, M., López-Barrios, M., \& Banegas, D. (2021). Research on English language teaching and learning in Argentina (2014-2018). Language Teaching, 1-33. 
awareness of their own pronunciation.

In her study, Panzachi Heredia (2017) aimed to determine the impact of nuclear stress placement on intelligibility and comprehensibility. A group of 29 upper-intermediate ELTE students were divided into three experimental groups corresponding to three versions of a recorded text: one with correct accentuation (A), one in which accents were placed on words not carrying new or contrasting information (B), and one with no nuclear stress (C). Members of the three experimental groups were further divided into three blocks according to their listening performance: top, average and low. The first task consisted in taking notes of the content and to pay attention to a sound signal that would be audible at some point in the recording. Subjects were required to click the computer mouse when they heard this sound, so that the time lapse between the sound signal and the mouse click could be determined as a measure of reaction time. The aim of this operation is not explained in the paper, so that readers have to resort to the study from which it was drawn (Hahn, 2004, in Panzachi Heredia, 2017) to understand its relevance. The second task consisted of a multiple-choice listening task. Findings showed that target-like accent placements (A) allowed faster comprehension than the two other versions $(\mathrm{B}, \mathrm{C})$ of the lecture, as measured by the time lapse between the sound signal and the mouse click, which suggested that the subjects' attentional resources were demanded by the processing of the information with non-target like (B) or flat, accentless (C) versions of the lecture. Besides, listening comprehension skills were found to account for a comparatively higher performance, as subjects in each group belonging to those with the top performance in listening tests obtained the best results in the experiment. Consequently, accentuation was found to have an impact on comprehensibility especially for the subjects with weaker listening skills. In a related study, Vázquez and González (2016) investigated the influence of two pronunciation variables (sounds and sentence stress) and their influence on comprehensibility. The novelty of this study lies in the fact that it dealt with NNS' speech and NNS listeners, as This is a peer-reviewed, author-accepted manuscript of the following research article: Porto, M., López-Barrios, M., \& Banegas, D. (2021). Research on English language teaching and learning in Argentina (2014-2018). Language Teaching, 1-33. 
similar studies usually involve native speakers as listeners. Two groups of pre-intermediate teenage EFL learners in a private language school rated the comprehensibility of two recorded passages, one with faulty pronunciation of sounds and one with inappropriate use of sentence stress and engaged in two tasks: a free written recall of the main points in the texts and a true/false comprehension activity. Results revealed that both variables tended to affect comprehension to a similar extent, and thus contradict findings from studies with NSs judging NNs' output, as in the latter, inaccuracies in suprasegmentals tended to affect comprehensibility more than sounds. As in Panzachi Heredia's (2017) study, the reading of Hahn's research (2004) was necessary to know how the NNS input was obtained.

The first study of learner awareness of their pronunciation performance, (Perticone, 2017) explored the feasibility of perceptual training to raise awareness of advanced ELTE students' ability to detect L2 pronunciation features. The study is rooted in Flege's Speech Learning Model (1995, in Perticone, 2017) that focuses on those L2 sound features learners in this case, Spanish speakers - do not perceive as different on account of their proximity to L1 sounds. Both the production of the palate-alveolar affricates and the perception of fallingrising pitch accents were selected for analysis and samples of both features were intensified or altered using speech synthesis in order to train learners' perception skills. To this end, samples of 20 students' oral production were collected over a period of one academic year. Additionally, the experiment involved two perception tests (pre-test and post-test) for the analysis of falling-rising pitch accents, as well as a training session for recognition. Pre and a post-test results showed moderately positive effects in the recognition of the selected features. The second study, (Castellano et al., 2015) aimed to assess the impact of monitoring strategies on intermediate ELTE students. To this end, a group of 10 students were asked to record themselves reading selections from the pronunciation course materials and to self-assess their performance using a grid designed for self, peer and teacher assessment. For this longitudinal This is a peer-reviewed, author-accepted manuscript of the following research article: Porto, M., López-Barrios, M., \& Banegas, D. (2021). Research on English language teaching and learning in Argentina (2014-2018). Language Teaching, 1-33. 
research, the recordings were subsequently assessed by a peer and one of the instructors, so that the same performance was evaluated from three points of view. Subjects received the three assessments and were asked to reflect on them and work on the feedback. The analysis of the different data sources indicated positive gains in terms of learner performance. Regarding the learners' and peers' assessment of micro and macro levels of performance, the former concentrated more on individual sounds whilst the latter paid more attention to suprasegmental features. Questionnaire data also revealed that subjects found the experience highly beneficial.

One paper dealt with aspects of EFL learner grammar. In a descriptive study, Lopez and Viejobueno (2017) analysed the realisation of non-canonic syntactic structures (extraposition and clefting) in a corpus of argumentative essays written by advanced EFL majors. Students were taught these constructions in a prior seminar on syntax so that they were expected to have developed an awareness for the correctness and suitability of these constructions. Results indicated prominent use of extraposition (ex. to do this would be pointless / it would be pointless to do this) and very scant use of clefting (ex. It was a sweater that I bought / What I bought was a sweater). Authors hypothesised that the simpler structure of extraposition could account for its frequent use to the detriment of the more complex clefting patterns, and that the underuse of this structure could be an avoidance strategy.

In comparison with the previous review, the number of papers dealing with vocabulary and phonology has not changed, but there is a noticeable decrease in studies of learners' morphosyntactic development, which may point to a shift of interest after intense engagement around the topic. No papers deal with interlanguage pragmatics in the corpus reviewed. The recommendation made in the previous review still holds for the present one: there is a paucity of studies of learners of lower proficiency and in school contexts. This should be addressed to raise awareness of the effect of the conditions under which school

This is a peer-reviewed, author-accepted manuscript of the following research article: Porto, M., López-Barrios, M., \& Banegas, D. (2021). Research on English language teaching and learning in Argentina (2014-2018). Language Teaching, 1-33. 
learners develop L2 competence, so as to design suitable materials and teacher development initiatives for said contexts.

\section{Teaching English for academic and specific purposes}

English for academic (EAP) and specific purposes (ESP) is a well-established field in Latin America, and Argentina boasts a longstanding tradition. Papers in the corpus in line with these traditions have been classified in two groups: (1) experiences with reading comprehension processes, and (2) materials and studies of specialist genre and linguistic analysis. Despite this classification, it should be noted that a commonality across the papers is their focus on researching EAP and ESP practices and learner development through a textual grammar lens which draws on systematic functional linguistics (e.g., Anglada, 2020; Chappell, 2020).

\subsection{Reading}

Reading researchers in ESP/EAP are interested in discovering the factors that impinge on reading with the aim of enabling students' access to research published in English. This body of work is considerable and addresses non-English majors with some degree of specialist knowledge but limited L2 proficiency. The nine papers in this section have been grouped in three categories. Firstly, studies that determine a specific difficulty resulting from the linguistic features of specialist discourse both at the more local (lexico-grammatical) or global (textual) levels, or the influence of learner variables that constrain comprehension. Second, those of explanatory nature that consist in testing a hypothesis or studying the effect of certain variables on reading performance. Thirdly, papers reporting the design and

This is a peer-reviewed, author-accepted manuscript of the following research article: Porto, M., López-Barrios, M., \& Banegas, D. (2021). Research on English language teaching and learning in Argentina (2014-2018). Language Teaching, 1-33. 
implementation of a course or teaching experience.

The papers by Cascone, Meoño Ortiz and Rezzano (2014), Delmas, Roseti, González, De Francesco and Regueira (2015), González, Albini and Rocca (2017) and González, Otero and Rocca (2014) conform the first group. Cascone et al. (2014) set out to inquire about ESP students' ability to establish cause-effect (CE) relationship on different functional levels (textual, logical and experiential) in a popular science text. A total of 48 students enrolled in the first-level extracurricular English course were asked to carry out two reading tasks to identify CE relationships. Results indicate a higher number of CE relationships were identified at the experiential level compared to those at the logical level. These findings show which types of $\mathrm{CE}$ markers should be the focus of explicit instruction to enable L2 readers to interpret causal relationships more effectively. In their study, Delmas et al. (2015) posited that the type of rhetorical organisation of a specialist text (1: expositive and 2: debate (a) with consecutive or (b) alternate organisation) impinges on the quantity and quality of information that can be immediately retrieved. To test this hypothesis, students in an advanced ESP course were divided in groups according to a reader profile established by a standardised test to measure their English lexico-grammatical knowledge and their skill in L1 reading. After completing reading tasks involving texts with the three argumentative sequences, results demonstrated that students recalled more information from the texts with the first two types of argumentative sequences and less from the texts of the alternate organisation type. This indicates that more emphasis needs to be made on this type of rhetorical organisation when designing instructional practices. Drawing on genre analysis, information processing and systemic functional linguistics, González et al. (2017) investigated the linguistic resources used in the conclusions of abstracts in research articles (RA) of two areas of the humanities. A linguistic analysis showed that conjunctions, logical metaphors or no particular resources were employed to state conclusions in RA. To test which of the three better aided ESP This is a peer-reviewed, author-accepted manuscript of the following research article: Porto, M., López-Barrios, M., \& Banegas, D. (2021). Research on English language teaching and learning in Argentina (2014-2018). Language Teaching, 1-33. 
students' understanding, an instrument was created consisting of three versions of one abstract from both linguistics and art: one containing a conjunction, one with an ideational metaphor, and one in which the conclusions section was not specifically marked as such. Three random groups of students of the intermediate level reading comprehension course read two abstracts and formulated both a general hypothesis based on the bibliographic references and a specific one based on the abstract. Data analysis showed that conclusions introduced by a logical metaphor best focused readers' attention to that section of the abstract than those which did not make use of a particular marker. Regarding the effect of learner variables on reading comprehension, González et al. (2014) observed the influence of the students' self-reported English proficiency and their university experience, operationalised in terms of the number of courses taken thus far in the programme, influenced the results on their performance in two reading tasks: a summary of the main ideas and an outline of the discussion section of the article, both formulated in Spanish. Data were obtained from two intact groups of humanities students on an intermediate level ESP course. Prompted by the noticeable differences found in the performance of both tasks by both groups, authors checked the results against the information concerning both learner variables and found a possible explanation for the discrepancy.

The second group includes the experimental studies by González and Albini (2018), Bron, De Francesco and Roseti (2016) and González Carrera, Sosa and Cardozo (2017). The longstanding experience of researching specialist academic discourse and its impact on teaching and learning in university ESP courses led González and Albini (2018) to explore the impact of familiarising students with the mini genre of research article abstracts. This is necessary, authors contend, because the genre circulates outside the students' field of experience so that they may be unaware of its functions and characteristics. The project, involving two groups of humanities students taking the intermediate level ESP course, started This is a peer-reviewed, author-accepted manuscript of the following research article: Porto, M., López-Barrios, M., \& Banegas, D. (2021). Research on English language teaching and learning in Argentina (2014-2018). Language Teaching, 1-33. 
with testing their degree of access to the main ideas in three versions of an abstract from the field of applied linguistics according to its rhetorical organisation: canonic, and two variants of non-canonic organisation. Results of the pre-test indicated that students who analysed the non-canonic version retrieved the least information, thus demonstrating the impact of type of rhetorical organisation on comprehension. After a pedagogic intervention, the post-test showed that instruction led to improved student performance. Apart from abstracts, titles of research articles constitute a first approximation to a specialist text on which readers base their initial hypotheses regarding the content dealt with in the paper. Nevertheless, the complexity English nominal constructions pose to Spanish-speaking ESP students led Bron et al. (2016) to address the comprehension difficulty of said constructions at a semanticpragmatic level and to explore the effectiveness of their explicit instruction. To this end, authors elaborated a pedagogic intervention based on a classification of three types of nominal constructions and tried it for two months with a group of university ESP students. The test administered after the intervention indicates a low performance around the $50 \%$ mark in the experimental group and very similar results for the control group, which suggested that the length of the intervention may not have been enough to produce a significant difference. Besides, authors suggest that depending on the complexity of the title, tasks could require reading the abstract first to allow a first approximation to the text. In an intervention study carried out with engineering undergraduates, González Carrera et al. (2017) examined the effect of providing marginal L1 glosses in reading texts on learning and retaining vocabulary over time, and its impact on reading comprehension. About 200 students in their first level of English attended lessons specifically designed to this aim. Results from vocabulary and reading comprehension tests using an unglossed text indicated that although no significant mean difference could be observed, the experiment revealed that the group achieved a higher level of reading comprehension than that of the previous year, whose

This is a peer-reviewed, author-accepted manuscript of the following research article: Porto, M., López-Barrios, M., \& Banegas, D. (2021). Research on English language teaching and learning in Argentina (2014-2018). Language Teaching, 1-33. 
grades served as a control measure, as those students had not been introduced to the glossing technique.

Reports of experiences in the teaching of ESP/EAP reading build the third group, with papers by Innocentini, Forte and Feraco (2017) and Martínez and Picchio (2014). Innocentini et al. (2017) report on an innovative type of reading comprehension task that required responding to hypothetical reasons why a specific text could be useful to fulfil a real-life purpose for students' future professional needs. These problem-solving tasks were implemented in an ESP course for agricultural students with the purpose of fostering critical thinking as well as their strategic and communicative competence. Task cycles included the analysis of the problem, the selection of readings providing theoretical and empirical data, and the presentation of the findings. Thus, the tasks proved successful in the attainment of the intended aims of going beyond the mere extraction of information from a text. Martínez and Picchio (2014) described the design and implementation of a course for low English proficiency social science masters aiming at the development of academic reading skills. This type of course is a standard requirement in virtually every course of study in Argentina, as English is firmly established as the global language of scientific communication, a fact that is bemoaned by a number of scholars, as competent users of English are put in a privileged situation compared to low proficiency EFL users, thus restricting their access to and participation in the global scientific community. The course had a duration of 40 hours and materials consisted of a corpus of scientific articles chosen partly by the instructors and partly by the participants. The final assessment, a home assignment involving the search and description of research articles in line with the participants' MA thesis projects, was successfully completed by most of the participants.

Both the previous review and this one report a similar number of papers related to

This is a peer-reviewed, author-accepted manuscript of the following research article: Porto, M., López-Barrios, M., \& Banegas, D. (2021). Research on English language teaching and learning in Argentina (2014-2018). Language Teaching, 1-33. 
research in ESP/EAP reading, and the interest in both the description and reading practices of academic genres, notably abstracts, expands to different academic disciplines. We expect further growth in this area in the coming years, given the influence of Systemic Functional Linguistics in Applied Linguistics research in Argentina.

\subsection{Genre and linguistic analysis}

In this section, we focus on genre and linguistic analysis. Researchers interested in this dimension explicitly say they aim to enable their students to improve comprehension and production skills in the specific genres that are frequent in their particular disciplines. Four studies describe academic genres in different disciplines (Busso \& Lopez, 2017; Delfederico \& Weht, 2017; Cardini \& Soliz, 2017; Moyetta, 2017) and two analyse lexical characteristics (Dúculi, Muñoz, \& Beck, 2015; Cardinali \& Waicekawsky, 2017).

In a broad descriptive study, Busso and Lopez (2017), Delfederico and Weht (2017), Cardini and Soliz (2017) and Moyetta (2017) listed and classified the academic and professional genres in English that exist in four academic fields, namely Chemistry, Economic Sciences, Medicine and Industrial Design respectively. In all cases, the authors carried out document analysis using the bibliography lists of the obligatory subjects in the specific courses of studies. They first listed the documents in English, classified them in genres and then characterised those genres using genre and textual linguistics theories as well as multilevel typologies. Findings showed the prevalence of key genres in each discipline: university book, research article in journal, best practices handbook and farmacopea (Chemistry and Pharmacy), university book, journal article, research project, abstract, and leaflet among others (Economic Sciences), medical essay (Medicine) and university book and research article (Industrial Design). Four levels of analysis were undertaken for each genre, This is a peer-reviewed, author-accepted manuscript of the following research article: Porto, M., López-Barrios, M., \& Banegas, D. (2021). Research on English language teaching and learning in Argentina (2014-2018). Language Teaching, 1-33. 
namely situational/contextual, functional, semantic and formal. In general, there seems to be some confusion as to what counts as 'genre' since for example 'dictionary', 'journal' and 'conference' were identified as genres. All authors concluded by highlighting the importance of curricular diversification and widening to familiarize students with the relevant genres in their fields, some of which were under-represented in the materials that undergraduates encountered, particularly in Medicine. Worth mentioning is the fact that only Cardini and Soliz (2017) sought triangulation by surveying experts and students regarding their perceptions of usual genres in Medicine at their university and by comparing the researchers' emerging list of genres with an available taxonomy in the field.

Two papers focus on lexical analysis of specialised discourse (Cardinali \& Waicekawsky, 2017; Dúcculi, Muñoz \& Beck, 2015). Motivated by the need to compile a specific word list for the field of ecology, Dúcculi, Muñoz and Beck (2015) set out to compile a corpus of research articles of that discipline. After a general analysis of the corpus, high frequency and high range words were identified and recategorised according to semantic and pragmatic criteria. Then, the total number of words (types) as well as their frequency (tokens) and range (number of texts in which words appear) were identified and the relation between types and tokens was computed as well. Words were then classified according to three categories (general, academic and grammatical), and the coverage of each category in the corpus was determined. A considerable number of high frequency and high range words were identified as general and academic lexis. Since they were all recognised as belonging to the specialised field of ecology, authors posit the unsuitability of this classification and propose a reclassification into technical and nontechnical words, according to contextual constraints, which could yield more usable data for the design of ESP/EAP curricula and materials. Cardinali and Waicekawsky (2017) carried out a study with qualitative methodology aimed at identifying specific lexis in the field of geology to compile a corpus of This is a peer-reviewed, author-accepted manuscript of the following research article: Porto, M., López-Barrios, M., \& Banegas, D. (2021). Research on English language teaching and learning in Argentina (2014-2018). Language Teaching, 1-33. 
specific vocabulary to aid in materials design. Using the theoretical framework provided by the system of appraisal (Martin \& White, 2005) that proposes tools for the identification, analysis and interpretation of the resources that create evaluative prosodies, the researchers analyzed the Introduction and Discussion of two research articles in English (Applied Linguistics and Psychology) with the purpose of identifying the prosodies that are construed in these segments in order to compare them and describe their use in different fields. Findings indicated that researchers construed evaluations and established prosodies strategically in relation to the arguments that were presented in the segments in agreement with their rhetorical function and the construal of the researcher's identity. Even though potentially interesting pedagogic implications are hinted at, the use of only two research articles considerably limits the study's contributions to the field.

Overall, all the studies in this section point to the need to familiarize students with the academic genres they will be encountering when they enter their academic communities, with particular attention to genre characteristics at the contextual, functional, semantic/lexical and formal levels.

\section{Assessment}

This section reviews studies on assessment practices in the development of language skills and the acquisition of the language systems, as well as with the evaluation of foreign language teaching programmes. A commonality across the studies is the authors' deployment of corpus analysis to examine learning artefacts such as assignments.

Research on assessment of language areas focuses on writing (Dalla Costa, Martínez, \& Romano, 2016; Canavosio, Salinas \& Basso, 2017; Romano \& Martínez, 2017), This is a peer-reviewed, author-accepted manuscript of the following research article: Porto, M., López-Barrios, M., \& Banegas, D. (2021). Research on English language teaching and learning in Argentina (2014-2018). Language Teaching, 1-33. 
pronunciation (Capell \& Giménez, 2017; Bombelli \& Soler, 2017) and reading skills in EAP/ESP contexts (De Francesco, Lauría, \& Roseti, 2016). It is noteworthy that the papers on assessment of writing and pronunciation originate in research projects carried out at the National University of Córdoba and that they aim at standardising rating procedures with a view to improving assessment practices.

The papers dealing with the assessment of writing focus on inter-rater reliability. They all refer to the writing of expository essays by intermediate ELTE students collected during formal assessment practices such as final exams. Dalla Costa et al. (2016) analysed five samples representing qualitatively different productions. Results indicated that the quantifiable language features of the written production exhibited higher levels of inter-rater reliability whilst assessors produced more discrepant judgements in the more qualitative aspects (content and organisation), thus indicating an area of lower inter-rater reliability. Findings supply valuable information to assist in the development of more reliable rating instruments. Another study by Romano and Martínez (2017) focused on the assessment criteria used by seven course instructors, and the relation between the criteria and the aspects of the writing focused on when marking. Each instructor selected two papers marked by them and wrote a report describing and justifying their decisions. Both the corrections and the raters' observations were analysed in terms of how raters judged the accuracy, content and organisation of the written productions, so as to determine the areas of agreement and disagreement among the assessors. The reports were submitted to content analysis and the emerging information was classified according to the three categories. Results indicated that organisation and content stand out as the strongest indicators of successful task completion, and content development was found to be the most frequent cause of failure in the samples that were below the passing standards. In a related study, Canavosio et al. (2017) analysed the comments related to language use and content and organisation formulated by the raters in a corpus of 257 essays to establish the relative weight This is a peer-reviewed, author-accepted manuscript of the following research article: Porto, M., López-Barrios, M., \& Banegas, D. (2021). Research on English language teaching and learning in Argentina (2014-2018). Language Teaching, 1-33. 
attributed by the assessors to both areas, and to determine the quality of the comments in terms of positive or negative feedback, and their nature, as general or specific comments. More comments were made on content/organisation (80\%) than on language use $(20 \%)$, thus revealing the importance given to the latter by the raters, and most of the comments in both areas were classified as negative (over 90\%). General comments about language use were more frequent than specific ones, whereas around $70 \%$ focused on content and $30 \%$ on organisation, and general comments outweighed specific ones. Like the study by Romano and Martínez (2017), this one also revealed students had more difficulty in the content area than in organisation or accuracy, thus providing valuable information concerning task design.

Two studies deal with the assessment of pronunciation. Capell and Giménez (2017) investigated the pronunciation features skilled raters pay most attention to when assessing the oral production of post-intermediate ELTE students. To this end, a group of 22 students completed two typical exam tasks: reading aloud a familiar dialogue and carrying out a conversation in response to a prompt given. For this study, authors selected the samples by the top and the weakest performer and found they both exhibited a more differentiated performance at the micro level (e.g., tone unit division, prominence, pauses, segmental production) than at the macro level, (intelligibility and fluency). The analysis of the five raters' marking of the performance of these two candidates indicated that raters tend to concentrate more on the micro than on the macro aspects and that the acceptable performance of the low performer at the macro level was overshadowed by the poor handling of the micro level components. The paper by Bombelli and Soler (2017) focused on inter-rater reliability in the assessment of pronunciation of advanced EFL majors. Authors aim to establish the reliability of three assessment methods: impressionistic, using a holistic and an analytic rating scale, and state the hypothesis that rating scales will prove more reliable than impressionistic marking. Five experts rated 32 recordings of students' oral performance consisting in reading a short tale This is a peer-reviewed, author-accepted manuscript of the following research article: Porto, M., López-Barrios, M., \& Banegas, D. (2021). Research on English language teaching and learning in Argentina (2014-2018). Language Teaching, 1-33. 
aloud and a brief individual oral presentation, and rated it using the different instruments. The statistical treatment of the data indicated significant differences in the means of each assessment procedure and pointed to the higher reliability of analytic scales. Authors concluded with a number of caveats that surfaced along the practice of using this instrument in real exam conditions and identified measures to be implemented to improve it.

The study by De Francesco et al. (2016) originated in the field of ESP/EAP and aimed at testing an instrument to assess students' reading comprehension skills through the reformulation of different kinds of texts in L1. Authors analysed samples from 269 first-year non-language majors non-randomly divided into a control and an experimental group. The final exam task consisted in the L1 formulation of a hypothesis based on the title and the abstract of a research article related to the students' field, and the writing of a sentence synthesising the content of the abstract. The students' productions were assessed firstly in terms of the clarity in the expression of the ideas and, if they satisfied this criterion, the interpretation of the content was subsequently rated. Using an ad hoc rating instrument consisting of analytic band scales describing the performance in both criteria, expression was rated according to its coherence and content respect to its correctness. Authors justified the usefulness of these assessment tasks on the principles of authenticity (a real task in the professional context), interactivity (the possibility of accessing information in L2) and construct validity (tasks are based on a predefined conception of reading comprehension), and recognised its usefulness in ensuring rater reliability.

The last two papers deal with a) the implementation of a foreign language teaching programme at a national university and b) secondary school learners' L2 reading comprehension skills in a school district. Gastaldi, Grimaldi and Mónaco (2016) evaluated the programme implemented at Litoral National University (UNL) that departs from the typical

This is a peer-reviewed, author-accepted manuscript of the following research article: Porto, M., López-Barrios, M., \& Banegas, D. (2021). Research on English language teaching and learning in Argentina (2014-2018). Language Teaching, 1-33. 
ESP/EAP reading comprehension course deployed at Argentinian universities and focuses on the development of the four skills and communicative ability. Authors analysed the different dimensions that impinge on the programme: normative, curriculum, instructors, students and infrastructure. Data was collected from a total of 755 students and 37 instructors, and interviews were conducted with the academic secretaries of the schools that conform the UNL in order to seek their opinion of the programme. Survey data indicated that both students and teachers largely agreed on their positive views, and provided information, together with the interview data, to make recommendations regarding the normative, curriculum, students and instructors dimensions. Regueira, Williams and Caielli (2017) reported on the implementation of a research project under way at the National University of Mar del Plata that aimed at testing the reading comprehension skills attained by secondary school students in their final class. By engaging in this endeavour, the team aimed at extending their research activities to the educational community by providing an external evaluation of one key skill learners should have developed by the end of secondary school. In this paper, authors described the piloting stage with a sample of around 100 students from public and private schools in the local school district. The pilot tests involved solving closed and open-ended reading comprehension activities set around three text types: an argumentative article, an information leaflet and a fable, as an exponent of narration, which are indicated in the local and national curricula. Results of the piloting stage allowed adjustments in the instrument for its future large-scale implementation.

On balance, research on assessment has experienced a remarkable growth compared to the previous review, in which three papers were reported against eight in the time span reported here. As said, research focused on assuring inter-rater reliability features prominently, thus making a valuable contribution to the improvement of assessment practices. Although the previous review recommended engaging in assessment in the context of learning disabilities as This is a peer-reviewed, author-accepted manuscript of the following research article: Porto, M., López-Barrios, M., \& Banegas, D. (2021). Research on English language teaching and learning in Argentina (2014-2018). Language Teaching, 1-33. 
well as in self-assessment, these remain as desiderata.

\section{Language curriculum development}

In this review materials, published and teacher-made, and course design and evaluation are understood as realisations and components of language curriculum development (Mickan \& Wallace, 2020). On a close reading of the publications collected, three foci emerge: (1) curriculum evaluation at the levels of policy, syllabus and course implementation, (2) materials development, and (3) coursebook evaluation. A common thread across such foci is authors' interest in understanding the tensions and possibilities between policy and practice; hence their adoption of document analysis and/or small-scale intervention projects that seek to align L2 provision and learner needs.

In the first group, researchers showed an interest in understanding the historical and educational reasons behind foreign language provision in primary (Varela \& Verdelli, 2016) and university education (Carbonetti \& González, 2016). Both studies agree that instrumental motives have pushed the overwhelming presence of English at the expense of other languages particularly in the state sector. In private schools with heritage links, other languages such as French, Italian, or German are offered. In university education, undergraduate courses in biology, medicine or chemistry only offer English; whereas courses in philosophy or sociology offer courses in German or French together with English.

Within the first focus, Esquerre (2016) analysed the curriculum of an initial English language teacher education programme to determine the extent to which its main objectives are realised in the modules offered and its assessment rationale and criteria. The author found a strong correlation between such elements of a programme but she noted the absence of elements which could encourage continuing professional development after graduation. This is a peer-reviewed, author-accepted manuscript of the following research article: Porto, M., López-Barrios, M., \& Banegas, D. (2021). Research on English language teaching and learning in Argentina (2014-2018). Language Teaching, 1-33. 
While Esquerre's (2016) study remained at document analysis, Mayol (2014) is an example of course implementation and evaluation. Through a survey-based study, she asked her ESP learners to measure the effectiveness of the content, material, and teaching strategies underpinning her ESP courses.

Concerning materials development, two studies emphasised the need for teachers to create and examine their own materials in higher education, particularly in ESP and ELTE courses. Fernández and Tavella (2016) created their own materials and adapted published coursebooks in order to respond to their ESP learners' language needs and cultural identities. By means of feedback sheets, the authors concluded that their materials enhanced learner motivation and autonomy as the texts and activities were contextualised in the learners' reality and future needs. In the context of higher education, Gómez Calvillo, Moyetta and Negrelli (2016) analysed and adapted their materials for a reading comprehension course so that learners could benefit from contrastive analysis between Spanish (L1) and English in order to extract meaning out of texts without overreliance on English grammar. Despite the promising outcomes of this study, the project did not include implementation and evaluation of effects among the learners.

The remaining focus on coursebook evaluation is represented in six publications. Three of those concentrated on the teaching of collocations in EFL coursebooks used in secondary education in Argentina (Natal, Suárez, \& Tuero, 2016, Suárez \& Tuero, 2015; Suárez, Tuero, \& Natal, 2017). The authors concluded that collocations are not included systematically in the coursebooks and that their presence needs careful treatment as regards sequencing and recycling. Requena, Liruso, and Bollati (2016) analysed the visual component of EFL coursebooks to understand the nature of visual interaction for the development of visual literacy and critical thinking. The results yielded that the coursebooks offered little engagement with the target audience, young learners, as visuals mostly fulfilled This is a peer-reviewed, author-accepted manuscript of the following research article: Porto, M., López-Barrios, M., \& Banegas, D. (2021). Research on English language teaching and learning in Argentina (2014-2018). Language Teaching, 1-33. 
a cosmetic and decorative purpose. In two different studies de-Matteis (2017) and Ferrara (2017) examine coursebooks for English for aviation and general English respectively. Both studies suggest that teachers should select coursebooks on a clear criteria based on contextual affordances and learner needs.

While the studies reviewed in this section offer insights into curriculum manifestations such as course design implementation and materials, researchers interested in this area should aim at producing in-depth publications which draw on triangulation and rigorous quantitative and qualitative analysis. Studies in this area should also be based on updated theoretical underpinnings; however, we are aware of the lack of economic resources to access quality articles published in high-impact journals.

\section{A focus on research practices}

In this section we briefly turn our attention to the research traditions and practices observed in the ELT professional community of practices represented in this review.

The studies synthesised above around nine different but intertwined themes illustrate a variety of deep-seated research approaches in the field of language teaching. Small-scale qualitative studies as well as single or multiple-case studies (e.g., Roccia \& Sacchi, 2015) often based on the authors' own practices or contextual proximity feature interviews, classroom observations (e.g., Basabe \& Germani, 2014), or, to a lesser extent, ethnographic narrative inquiry (e.g., Sarasa, 2017). Quantitative studies have been deployed to understand, for example, student-teachers' perceptions through online surveys (e.g., Soto, 2014; Soto \& Waigandt, 2018), students' writing performance through corpus-based research (e.g., Oliva \& Maussion, 2017), or students' linguistic performance through tests as part of quasiexperiments/interventionist studies which include control and experimental groups (e.g., This is a peer-reviewed, author-accepted manuscript of the following research article: Porto, M., López-Barrios, M., \& Banegas, D. (2021). Research on English language teaching and learning in Argentina (2014-2018). Language Teaching, 1-33. 
Vázquez \& González, 2015). Mixed-method approaches have also been identified, usually in the form of sequential research where a quantitative-oriented survey is followed by interviews (e.g., Valsecchi et al., 2016). Other research traditions identified have been action research, which includes the analysis of learning and teaching artefacts such as learner-made posters or teachers' lesson plans (e.g., Braun \& Monserrat, 2017; Spataro, 2015), document research in the form of curriculum (e.g., Esquerre, 2016) or coursebook (e.g., Ferrara, 2017) analysis, and arts-based approaches (e.g., Basabe et al., 2016).

In the broad context of ELT research in Argentina, the research traditions identified above seem to cluster around teacher research (Borg \& Sanchez, 2015). In other words, most of the studies were conducted by educators (teachers and/or teacher educators) with their own learners or intact classes. Hence, teacher research not only became an instrument of reviewing their own professional practice but also constituted a space which integrated professional development, teaching, learning, and inquiry in which in which research is an inherent element of teachers' practice. While teacher research contributes to the cement the practice-research nexus (Hanks, 2019) through small-scale studies which prioritise specific circumstances, we may need reports which aim at (1) including rigorous and sophisticated description of research methods to secure transparency, (2) engaging in various types of triangulation to ensure trustworthiness and confirmability, (3) moving beyond, in several cases, participants' self-reporting, and (4) ensuring that concluding statements are robustly substantiated on the findings included in the paper. Possibly due to the limited length of the articles or authors' knowledge of research or preference for teacher research, authors do not seem to describe ethical procedures, acknowledge limitations or discuss their findings through critical eyes and cross-referencing the literature, which, in most cases, appears outdated or fails to recognise the works of other colleagues within Argentina. Consequently, many of the studies may seem cryptic or difficult to replicate as there is little information that This is a peer-reviewed, author-accepted manuscript of the following research article: Porto, M., López-Barrios, M., \& Banegas, D. (2021). Research on English language teaching and learning in Argentina (2014-2018). Language Teaching, 1-33. 
can help readers fully comprehend the nature and meaning of the data collected.

As we constructed the corpus, two issues emerged which prompted us to eliminate several articles from the review. On the one hand, the questionable practice of salami slicing of data sets was found particularly around those who investigated formulaic sequences or individual learning strategies. In all these cases, the conceptual framework and research procedures were identical, and the findings, unsurprisingly almost identical. What could have been simply treated as data saturation was employed to increase the quantity of outputs at the expense of quality and researchers' reputation. On the other hand, but associated to the first issue, the misuse of data sets and the dissemination of findings in both Spanish and English has led to instances of paper near duplication or partial self-plagiarism. In this latter case, Argentinian authors may need to explicitly acknowledge in their papers that one version is based on another version and that the publication of a version in Spanish seeks to share the findings with colleagues in other fields (e.g., general education) or specialised in languages other than English. These two issues are both a warning and an invitation to reflect on local research practices, knowledge about research, and knowledge flow and impact within the community.

\section{Conclusion}

Considering the existing limitations and difficulties that exist in undertaking research in Argentina (lack of access to high impact publications and software for data analysis, difficulty of accessing the national system of teacher-researchers and the national research council Conicet, limited possibilities of training in research skills, among others), this review article shows that research in ELT in Argentina is broad and varied, and in tune with current international developments in the different fields explored.

This is a peer-reviewed, author-accepted manuscript of the following research article: Porto, M., López-Barrios, M., \& Banegas, D. (2021). Research on English language teaching and learning in Argentina (2014-2018). Language Teaching, 1-33. 
There are several areas in which further work is needed. First, research in Argentina tends to be conducted mainly in two contexts involving, on the one hand, university students majoring in ELT education, translation or English Studies, and on the other, university students from different areas of research who attend courses in English for academic or specific purposes. We believe that this focus is narrow and can be expanded by broadening two dimensions, namely context and participants. In terms of context, more research is needed in mainstream EFL classrooms in primary and secondary schools as well as in language schools. In terms of participants, studies focusing on beginners and older learners are scarce. In all cases, research tends to focus on universities and less often on schools, with almost no exploration of how language learning takes place in informal contexts, or the different funds of knowledge beyond universities and schools where learners live their lives and use languages every day such as the home, community centers, clubs, parks and so on. In all cases, the gaze is narrow too in the temporal span, with almost no longitudinal studies (see Coudannes et al., 2016) in any of the reported areas.

Second, research in language skills and language systems generally addresses reading and writing, with little attention to speaking and listening. We hypothesise that this limitation originates in traditional conceptions of literacy centered on the printed word, now outdated but still quite strong in the country as this review shows, and also on local contextual factors, mainly the fact that classrooms at all levels of education tend to be overcrowded - something that may discourage teachers from addressing speaking and listening more enthusiastically. In this regard, we also note that while technology-enhanced teaching could offer a solution, research in this period in this area shows that technology is used to merely complement and support existing programmes, modules and courses but not as an instrument to enable the development of these skills in genuine contexts, for example through transregional and transnational projects among foreign language students.

This is a peer-reviewed, author-accepted manuscript of the following research article: Porto, M., López-Barrios, M., \& Banegas, D. (2021). Research on English language teaching and learning in Argentina (2014-2018). Language Teaching, 1-33. 
Third, in terms of language teacher education, professional development and curriculum development, there is an overriding emphasis on teacher cognition, and teacher/student beliefs, perceptions and preferences. While this is important in order to have a clear portrait of the variation in this respect in the second biggest country in South America with $3779 \mathrm{~km}$ from north to south, there is an urgent need to explore what teachers and students actually do in classrooms and beyond classrooms, with innovative research designs that address the micro-dimensions of learning and go beyond the predominant use of instruments like surveys and questionnaires.

Fourth, some of the research we have reviewed, for instance on vocabulary and phonology, while of interest in themselves, present disturbing and challenging implications. Some of these studies are grounded on theories geared around the NS-NNS dichotomy and the concept of target-like proficiency. It is not surprising then that in this review translanguaging theories and translingual practices does not feature at all. We observe an urgent need to address this dimension, particularly as its social inclusion basis is significant for a country with several indigenous live languages (Aymara, Caiwá, Chiriguano, Chiripá, Chorote, Guaraní, Mapudungun, Wichí, Mocoví, Nivaclé, Pilagá, Quechua, Tapieté, Toba) as well as several heritage and foreign languages.

Fifth, the conceptualisations that emerge in this review of what language learning means are also a bit unsettling. We have already mentioned the preponderance given to conceptions of literacy around the print word, views of proficiency centered on linguistic competence and the native speaker as model and the lack of any reference to translanguaging. It is no surprise then that assessment focuses on language skills and the acquisition of language systems, with heavy attention to micro-elements and particular areas such as reading and writing. While we of course do not undermine their significance, we believe the focus needs to be complemented with the investigation of alternative forms of assessment

This is a peer-reviewed, author-accepted manuscript of the following research article: Porto, M., López-Barrios, M., \& Banegas, D. (2021). Research on English language teaching and learning in Argentina (2014-2018). Language Teaching, 1-33. 
that take account of learners as whole beings who can show their learning using all the languages and resources available to them. For this to happen, we envision that language assessment literacy (Levia \& Inbar-Lourieis, 2020) is an urgent need in our teacher education programmes in the country.

Finally, considering the current political scenario that has given rise to authoritarianism around the world, and in the midst of the world fight against coronavirus as we finish this article, the development and study the intercultural citizenship dimension of language education, which in this review is strong but minimal, seems imperative and inescapable. Intercultural citizenship education in the language classroom, but also across all levels of education and subject domains, is needed to foster democratic values based on an ethical relationship with others, both human and non-human (planet Earth, animals, plants, the environment). These values are those of solidarity, empathy, love, care and respect, among others, which can be developed using an intercultural citizenship basis that complements more utilitarian, however necessary, purposes. If our country had cultivated these values in schools and universities with due strength, our citizenry would now be willingly confined in their homes for the sake of the wellbeing of people they do not know and will never get to know.

\section{References}

(Given space limitations, titles are given in the original language(s) only. Readers interested in their English translations should contact the authors)

Alcaráz, P. (2015). E-pals and movie segments: Simple ways to introduce ICT in the EFL class. In A. Leceta \& R. Cúneo (Eds.), VI Jornadas de actualización en la enseñanza del inglés (pp. 62-72). San Juan: Universidad Nacional de San Juan.

Alcázar, M. J., \& M. Altamirano (2017). Aprendizaje léxico en inglés: Análisis de creencias

This is a peer-reviewed, author-accepted manuscript of the following research article: Porto, M., López-Barrios, M., \& Banegas, D. (2021). Research on English language teaching and learning in Argentina (2014-2018). Language Teaching, 1-33. 
y estrategias de adolescentes en dos instituciones privadas. In M. C. Barbeito, M. López-Barrios \& R. Pasquale (Eds.), Lenguas y culturas: Desafíos actuales de la diversidad y de la integración. Actas de las XV Jornadas y II Congreso Latinoamericano de Enseñanza de Lenguas Extranjeras en el Nivel Superior (Vol. III, pp. 101-119). Córdoba: Universidad Nacional de Córdoba.

Anglada, L. (2020). Reflections on English grammar instruction in EFL/ESL educational settings. In D. L. Banegas (Ed.), Content knowledge in English language teacher education: International experiences (pp. 49-64). London: Bloomsbury.

Amez. M., \& E. Dobboletta (2017). Pre-service and novice teachers' perceptions on second language teacher education. In D. L. Banegas (Ed.), Initial English language Teacher education: international perspectives on research, curriculum and practice (pp. 13-25). London/ New York: Bloomsbury.

Banegas, D. L., \& Manzur Busleimán, G. (2014). Motivating factors in online language teacher education in southern Argentina. Computers \& Education, 76(1), 131 - 142.

Banegas, D.L., \& Villacañas de Castro, L. S. (2016). Criticality. ELT Journal, 70, 455-457.

Barbeito, M., Placci, G., Ponce, S. \& Galfioni, G. (2016). Aprender inglés en la escuela secundaria. Descripción de las creencias de los estudiantes. In G. Maldonado, A. Bono, \& D. Sigal (Eds.), Qué investigamos en la Facultad de Ciencias Humanas: Actas de las Jornadas de Investigación de la Facultad de Ciencias Humanas 2015 (pp. 89-102). Río Cuarto: UniRío Editora.

Barkhuizen, G. (2020). Core dimensions in narrative inquiry. In J. McKinley \& H. Rose (Eds.), The Routledge handbook of research methods in applied linguistics. London/New York: Routledge.

Basabe, E. \& Germani, M. P. (2014). Reading for life: The Critical Literacy and Literature Project at UNLPam (2013-2016). Argentinian Journal of Applied Linguistics, 2(1), 32-

This is a peer-reviewed, author-accepted manuscript of the following research article: Porto, M., López-Barrios, M., \& Banegas, D. (2021). Research on English language teaching and learning in Argentina (2014-2018). Language Teaching, 1-33. 
41.

Basabe, E. (2016). La literatura en el profesorado en inglés: Formadores docentes y modelos curriculares. In M. Gastaldi \& E. Grimaldi (Eds.), Políticas lingüísticas y lenguas extranjeras en el nivel superior (pp. 99-109). Santa Fe: Universidad Nacional del Litoral.

Basabe, E., Tamagni Baigorria, G. \& Schiel Yicarean, J. (2016). Experiencing Visual Literacy through Art and Selfies in English Language Teacher Education. ARTESOL EFL E-Journal, 1(3), 31-41.

Bigelow, M. (2019). Perspectives: (Re)considering the role of emotion in language teaching and learning. The Modern Language Journal, 103, 515-544.

Bloor, T., \& Bloor, M. (2004). The functional analysis of English (2nd ed.). London: Arnold. Bombelli, B. \& Soler, L. (2017). Estudio sobre la confiabilidad en la evaluación de la pronunciación en inglés como LE. In F. Ávalos, H. Gargiulo, J. J. Rodríguez \& E. Villanueva de Debat, (Eds.) (2017). Desafíos actuales de la diversidad y de la integración. Actas de las XV Jornadas y II Congreso Latinoamericano de Enseñanza de Lenguas Extranjeras en el Nivel Superior. Volumen II (pp. 52-65). Córdoba: Universidad Nacional de Córdoba. Libro digital, PDF.

Borg, S. (2006). Teacher cognition and language education: Research and practice. London: Continuum.

Borg, S., \& Sanchez, H. S. (Ed.). (2015). International perspectives on teacher research. Basingstoke: Palgrave.

Braun, E. (2015). Assessment of an intercultural education project at primary school level. In L. Anglada, N. Sapag, D. Banegas \& M. Soto (Eds.), EFL classrooms in the new millennium: Selected papers from the 40th FAAPI Conference (pp. 32-42). Córdoba: ACPI.

This is a peer-reviewed, author-accepted manuscript of the following research article: Porto, M., López-Barrios, M., \& Banegas, D. (2021). Research on English language teaching and learning in Argentina (2014-2018). Language Teaching, 1-33. 
Braun, E. N., \& Monserrat, L. I. (2017). La dimensión intercultural en las aulas de inglés en colegios secundarios de La Pampa. In M. Baduy, A. Bogliotti, M. Ledesma \& A. Pérez (Eds.), Lenguas y culturas: Desafios actuales de la diversidad y de la integración. Actas de las XV Jornadas y II Congreso Latinoamericano de Enseñanza de Lenguas Extranjeras en el Nivel Superior (Vol. VI, pp. 55-69). Córdoba: Universidad Nacional de Córdoba.

Bron, N., De Francesco, K. \& Roseti, L. (2016). Nominalizaciones complejas: Una tipología en la enseñanza de lectocomprensión en inglés. In M. Gastaldi \& E. Grimaldi (Eds.), Políticas lingüisticas y lenguas extranjeras en el Nivel Superior (pp. 167-176). Santa Fe: Universidad Nacional del Litoral.

Busso, N., \& Lopez, L. (2017). Géneros académicos y profesionales en inglés en el área de Ciencias Químicas en la UNC. In D. Moyetta, C. Raffo \& S. Rezzano (Eds.), Lenguas y culturas: Desafios actuales de la diversidad y de la integración. Actas de las XV Jornadas y II Congreso Latinoamericano de Enseñanza de Lenguas Extranjeras en el Nivel Superior (Vol. V, pp. 46-63). Córdoba: Universidad Nacional de Córdoba.

Byram, M. (2014). Twenty-five years on - from cultural studies to intercultural citizenship. Language, Culture and Curriculum, 27, 209-225.

Byram, M. (2016). Foreign language learning after Brexit. Public lecture. University of East Anglia. Available from https://www.uea.ac.uk/lcs/events/public-lectures/2016/2017public-lectures

Byram, M. (2018). An essay on internationalism in foreign language education. Intercultural Communication Education, 1(2), 64-82.

Caielli, E., \& Williams, J. (2018). Análisis crítico del discurso en la formación docente. Una experiencia con profesores de inglés de escuelas en situación de desfavorabilidad. Lenguas V;vas, 14, 23-36.

This is a peer-reviewed, author-accepted manuscript of the following research article: Porto, M., López-Barrios, M., \& Banegas, D. (2021). Research on English language teaching and learning in Argentina (2014-2018). Language Teaching, 1-33. 
Calvo, A. I. \& Ríus, N. (2017). Las prácticas de escritura en el ingreso a la universidad: uso de recursos cohesivos. In. M. Romano \& B. Amado (Eds.), Lenguas y culturas: Desafios actuales de la diversidad y de la integración. Actas de las XV Jornadas y II Congreso Latinoamericano de Enseñanza de Lenguas Extranjeras en el Nivel Superior (Vol. I, pp. 46-56). Córdoba: Universidad Nacional de Córdoba.

Canavosio, C., Salinas, J. \& Basso, F. (2017). Análisis de comentarios docentes sobre escritura en lengua extranjera (inglés). In F. Ávalos, H. Gargiulo, J. Rodríguez \& E. Villanueva de Debat, (Eds.) (2017). Desafios actuales de la diversidad y de la integración. Actas de las XV Jornadas y II Congreso Latinoamericano de Enseñanza de Lenguas Extranjeras en el Nivel Superior. Volumen II (pp. 92-105). Córdoba: Universidad Nacional de Córdoba.

Cangialosi, F. (2016). Exploring the theme and rheme organization of articles written by EFL university students in Argentina. In D. L. Banegas, M. López Barrios, M. Porto, \& A. Soto (Eds.), ELT as a multidisciplinary endeavour: selected Papers from the XLI FAAPI Conference (pp. 73-83). San Juan: Universidad Nacional de San Juan. Facultad de Filosofía, Humanidades y Artes.

Capell, M.S. \& Giménez, F. (2017). La evaluación de la pronunciación del inglés en la universidad: aspectos determinantes para su valoración. In F. Ávalos, H. Gargiulo, J. Rodríguez \& E. Villanueva de Debat, (Eds.) (2017). Desafíos actuales de la diversidad y de la integración. Actas de las XV Jornadas y II Congreso Latinoamericano de Enseñanza de Lenguas Extranjeras en el Nivel Superior. Volumen II (pp. 41-51). Córdoba: Universidad Nacional de Córdoba.

Carbonetti, M., \& González, L. (2016). La normativa: ¿qué lenguas se deben aprender en la universidad? In M. Gastaldi \& E. Grimaldi (Eds.), Políticas lingüisticas y lenguas extranjeras en el Nivel Superior (pp. 44-52). Santa Fe: Universidad Nacional del

This is a peer-reviewed, author-accepted manuscript of the following research article: Porto, M., López-Barrios, M., \& Banegas, D. (2021). Research on English language teaching and learning in Argentina (2014-2018). Language Teaching, 1-33. 
Litoral.

Cardinali, R., \& Waicekawsky, L. (2017). El rol de la prosodia valorativa en artículos de investigación en inglés. Cronía, 17(13), 53-63.

Cardini, M. N., \& Soliz, M. E. (2017). Los géneros académicos en inglés en la carrera de Medicina de la UNC. In D. Moyetta, C. Raffo \& S. Rezzano (Eds.), Lenguas y culturas: Desafíos actuales de la diversidad y de la integración. Actas de las XV Jornadas y II Congreso Latinoamericano de Enseñanza de Lenguas Extranjeras en el Nivel Superior (Vol. V, pp. 78-88). Córdoba: Universidad Nacional de Córdoba.

Carter, R., \& Long, M. (1991). Teaching literature. Harlow: Longman.

Cascone, L., Meoño Ortiz, M. \& Rezzano, S. (2014). Identificación y comprensión de relaciones causales en géneros explicativos en inglés: dificultades en lectores universitarios. LyCE Estudios, 17, 35-48.

Castellano, M., Garay, M. \& García, L. (2015). Using self-monitoring strategies to enhance university students' pronunciation skills. In L. Anglada, N. Sapag, D. Banegas \& M. Soto (Eds). EFL classrooms in the new millennium: selected papers from the 40th FAAPI Conference (pp. 110-119). Córdoba: ACPI.

Castiñeira, B., \& Mucci, M. R. (2014). Reading Comprehension in Interactions in the Virtual Campus. ARTESOL EFL E-Journal, 1(1), 12-21.

Castiñeira, B., \& Mucci, M. R. (2017). The Facebook experience for college reading and writing. ARTESOL EFL E-Journal, 1(4), 31-36.

Chapelle, C., \& Sauro, S. (2017). Handbook of technology and second language teaching and learning. Hoboken: Wiley Blackwell.

Chappell, P. (2020). A functional model of language for language teacher education. In D. L. Banegas (Ed.), Content knowledge in English language teacher education: International experiences (pp. 29-48). London: Bloomsbury.

This is a peer-reviewed, author-accepted manuscript of the following research article: Porto, M., López-Barrios, M., \& Banegas, D. (2021). Research on English language teaching and learning in Argentina (2014-2018). Language Teaching, 1-33. 
Consejo Federal de Educación (2012). Resolución CFE N 181/12: Núcleos de aprendizajes prioritarios para la educación primaria y secundaria - Lenguas Extranjeras. Buenos Aires.

Coudannes Aguirre M. \& Andelique, C. (2016). La enseñanza de la ciudadanía a partir de contenidos curriculares comunes. Un aporte a la investigación sobre la formación docente y los modos de vincularse a los contextos de las prácticas. Revista de educación, VII(9), 255-296.

Council of Europe (2018). Reference framework of competences for democratic culture.

Volumes 1-3. Strasbourg: Council of Europe. Available from:

https://www.coe.int/en/web/education/competences-for-democratic-culture

Dalla Costa, N. \& Gava, I. (2017). Effect of pre-writing activities through online forums on writing tasks. In D. Banegas, M. López-Barrios, M. Porto \& D. Waigandt (Eds.), Authenticity in ELT: selected papers from the 42nd FAAPI Conference (pp. 54-63). Posadas: APIM.

Dalla Costa, N., Martínez, J. \& Romano, M. (2016). Análisis de la concordancia entre evaluadores de textos en inglés como lengua extranjera. In M. Gastaldi \& E. Grimaldi (Eds.), Políticas lingüísticas y lenguas extranjeras en el Nivel Superior (pp. 575- 583). Santa Fe: Universidad Nacional del Litoral.

Dalla Costa, N., Martínez, J. \& Romano, M. (2016). Análisis de la concordancia entre evaluadores de textos en inglés como lengua extranjera. In M. Gastaldi \& E. Grimaldi (Eds.), Políticas lingüísticas y lenguas extranjeras en el Nivel Superior (pp. 575- 583). Santa Fe: Universidad Nacional del Litoral.

De Francesco, K., Lauría, S. \& Roseti, L. (2016). Evaluación cualitativa de lectura comprensiva en inglés: una propuesta de categorías analíticas. In M. Gastaldi \& E. Grimaldi (Eds.), Politicas lingüisticas y lenguas extranjeras en el Nivel Superior (pp.

This is a peer-reviewed, author-accepted manuscript of the following research article: Porto, M., López-Barrios, M., \& Banegas, D. (2021). Research on English language teaching and learning in Argentina (2014-2018). Language Teaching, 1-33. 
149- 157). Santa Fe: Universidad Nacional del Litoral.

De Laurentis, C. (2015). Rupturas y continuidades en la formación docente: Una experiencia en las aulas del profesorado de inglés. Revista de Educación, 8, 137-156.

Delfederico, G. \& Weht, G. (2017). Los géneros académicos en inglés prototípicos del área de las Ciencias Económicas. In D. Moyetta, C. Raffo \& S. Rezzano (Eds.), Lenguas y culturas: Desafios actuales de la diversidad y de la integración. Actas de las XV Jornadas y II Congreso Latinoamericano de Enseñanza de Lenguas Extranjeras en el Nivel Superior (Vol. V, pp. 64-77). Córdoba: Universidad Nacional de Córdoba.

Delmas, A., Roseti, L., González, M., De Francesco, K. \& Regueira, I. (2015). Las tramas argumentativas en la lecto-comprensión del discurso académico en inglés. $L y C E$ Estudios, 18, 121-147.

de-Matteis, L. (2017). Materiales de inglés aeronáutico como fuente para el desarrollo de competencias comunicativas en lengua materna. In L. Granato \& M. Negrín (Eds.), Asuntos de lingüística aplicada (pp. 87-102). Bahía Blanca: Editorial de la Universidad Nacional del Sur. Ediuns, Sociedad Argentina de Lingüística.

Dewaele, J. M. (2018). Editorial. Special issue "Emotions in SLA". Studies in Second Language Learning and Teaching, 8, 15-19.

Dúcculi, E., Muñoz, V. \& Beck, S. (2015). Estudio del vocabulario en un corpus de artículos de investigación de Ecología. Cronía, 11, 189-213.

Ellis, R. (2008). The study of second language acquisition (2nd ed.). Oxford: OUP.

Esquerre, A. (2016). Formando futuros formadores: Currícula, objetivos y evaluación. In M. Gastaldi \& E. Grimaldi (Eds.), Políticas lingüisticas y lenguas extranjeras en el Nivel Superior (pp. 120-127). Santa Fe: Universidad Nacional del Litoral.

Farrell, T. S. C. (Ed.). (2015). International perspectives on English language teacher education: Innovations from the field. Basingstoke: Palgrave.

This is a peer-reviewed, author-accepted manuscript of the following research article: Porto, M., López-Barrios, M., \& Banegas, D. (2021). Research on English language teaching and learning in Argentina (2014-2018). Language Teaching, 1-33. 
Fernández, C., \& Tavella, G. (2016). Material design in a context-sensitive practice. In M. Gastaldi \& E. Grimaldi (Eds.), Políticas lingüisticas y lenguas extranjeras en el Nivel Superior (pp. 222-228). Santa Fe: Universidad Nacional del Litoral.

Fernández, N. \& Raspa, J. (2016). La aplicación de las Inteligencias Múltiples en la enseñanza del inglés a estudiantes universitarios andragógicos In M. Gastaldi \& E. Grimaldi (Eds.), Políticas lingüísticas y lenguas extranjeras en el Nivel Superior (pp. 593-601). Santa Fe: Universidad Nacional del Litoral.

Fernández, N., Marchegiani, P., Picelille, S. \& Raspa, J. (2015). Andragogy and Multiple Intelligences: Two complementary views at university. In A. Leceta \& R. Cúneo (Eds.), VI Jornadas de actualización en la enseñanza del inglés (pp. 40-47). San Juan: Universidad Nacional de San Juan.

Ferrara, C. (2017). Challenging textbooks towards socio cultural emancipation. In M.

Gastaldi \& E. Grimaldi (Eds.), Políticas lingüísticas y lenguas extranjeras en el Nivel Superior (pp. 119-129). Santa Fe: Universidad Nacional del Litoral.

Gardner, H. (1983). Frames of mind: The theory of multiple intelligences. New York: Basic Books.

Gastaldi, M., Grimaldi, E. \& Mónaco, F. (2016) La enseñanza de idiomas extranjeros en la UNL: su evaluación tras una década de implementación de la propuesta vigente. In M. Gastaldi \& E. Grimaldi (Eds.), Politicas lingüísticas y lenguas extranjeras en el Nivel Superior (pp. 523- 531). Santa Fe: Universidad Nacional del Litoral.

Gava, I., Dalla Costa, N., \& Kofman, G. (2016). La enseñanza explícita de estrategias de aprendizaje de vocabulario en el nivel avanzado. In C. Padilla Sabaté \& D. Riestra (Eds.), Problemáticas en enseñanza y aprendizaje de lenguas (pp. 183-202). Bahía Blanca: Editorial de la Universidad Nacional del Sur. Ediuns, Sociedad Argentina de Lingüística.

This is a peer-reviewed, author-accepted manuscript of the following research article: Porto, M., López-Barrios, M., \& Banegas, D. (2021). Research on English language teaching and learning in Argentina (2014-2018). Language Teaching, 1-33. 
Gava, Y., \& Anglada, L. (2015). B-learning in an EFL college class: Creativity, critical thinking and collaboration. In L. Anglada, N. L. Sapag, D. L. Banegas \& M. A. Soto (Eds). EFL classrooms in the new millennium: Selected papers from the 40th FAAPI Conference (pp. 98-109). Córdoba: ACPI.

Gava, Y., \& Dalla Costa, N. V. (2018). A socio-cognitive approach to the development of EFL writing skills through a collaborative online discussion forum in a university course. Argentinian Journal of Applied Linguistics, 6(2), 6-25.

Ginevra, G.A. (2014). ¿Qué problemas enfrentan los estudiantes del nivel superior al escribir textos argumentativos en inglés? Un estudio descriptivo. LyCE Estudios, 17, 99- 121.

Gómez Calvillo, N., D. Moyetta, \& F. Negrelli (2016). Gramáticas en contraste: su rol en el diseño de materiales para la enseñanza de lectocompresion en lengua extranjera en el nivel superior. In M. Gastaldi \& E. Grimaldi (Eds.), Políticas lingüísticas y lenguas extranjeras en el Nivel Superior (pp. 249-258). Santa Fe: Universidad Nacional del Litoral.

González Carrera, G., Sosa, A. \& Cardozo, Y. (2017). Researching into the effects of L1 glosses on undergraduates' reading comprehension. In D. Banegas, M. López-Barrios, M. Porto \& D. Waigandt (Eds.), Authenticity in ELT: selected papers from the 42nd FAAPI Conference (pp. 41-53). Posadas: APIM.

González de Gatti, M., \& Sánchez, M. (2016). Enseñanza explícita de estrategias para la resolución de ejercicios de clasificación y formación de palabras. In C. Padilla Sabaté \& D. Riestra (Eds.), Problemáticas en enseñanza y aprendizaje de lenguas (pp. 203227). Bahía Blanca: Editorial de la Universidad Nacional del Sur. Ediuns, Sociedad Argentina de Lingüística.

González de Gatti, M. M., Orta González, M. D., \& Sánchez, M. V. (2016). Enseñanza explícita de estrategias de consolidación léxica para términos de un campo semántico.

This is a peer-reviewed, author-accepted manuscript of the following research article: Porto, M., López-Barrios, M., \& Banegas, D. (2021). Research on English language teaching and learning in Argentina (2014-2018). Language Teaching, 1-33. 
In C. Padilla Sabaté \& D. Riestra (Eds.), Problemáticas en enseñanza y aprendizaje de lenguas (pp. 228-251). Bahía Blanca: Editorial de la Universidad Nacional del Sur. Ediuns, Sociedad Argentina de Lingüística.

González de Gatti, M., Sánchez, M. \& Orta, D. (2017) Aprendizaje de vocabulario con similitudes morfológicas en inglés en el nivel superior. In. M. Romano \& B. Amado (Eds.), Lenguas y culturas: Desafios actuales de la diversidad y de la integración. Actas de las XV Jornadas y II Congreso Latinoamericano de Enseñanza de Lenguas Extranjeras en el Nivel Superior (Vol. I, pp. 136-148). Córdoba: Universidad Nacional de Córdoba.

González, M. \& Albini, M. (2018). Importance of abstracts as a mini academic genre. ARTESOL ESP E-Journal, 8(1), 19-26.

González, M. (2018). Teaching senior citizens: What they want from us. In D. Banegas, M. López-Barrios, M. Porto \& D. Waigandt (Eds.), Adapting to meet diverse needs in ELT. Selected Papers from the 43rd FAAPI Conference (pp. 46-58). Río Gallegos: APISC. González, M., Albini, M. \& Rocca, A. (2017). Dificultades de comprensión de abstracts escritos en inglés. In D. Moyetta, C. Raffo \& S. Rezzano (Eds.), Lenguas y culturas: Desafios actuales de la diversidad y de la integración. Actas de las XV Jornadas y II Congreso Latinoamericano de Enseñanza de Lenguas Extranjeras en el Nivel Superior (Vol. V, pp. 178-188). Córdoba: Universidad Nacional de Córdoba.

González, M., Otero, A. \& Rocca, A. (2014). Reading comprehension of an argumentative text macrostructure and its reformulation. ARTESOL ESP E-Journal, 4(1), 37-51.

Grundnig, M. \& Himelfarb, R. (2017). Fundamentos lingüístico-discursivos y psicolingüísticos de una propuesta didáctica para la enseñanza del léxico en lengua extranjera inglés en el nivel superior. In M. Fernández Beschtedt, A. Castro, P. Formiga, \& Z. Risso Patrón (Eds.), Zonas de contacto: culturas, lenguas y educación:

This is a peer-reviewed, author-accepted manuscript of the following research article: Porto, M., López-Barrios, M., \& Banegas, D. (2021). Research on English language teaching and learning in Argentina (2014-2018). Language Teaching, 1-33. 
Actas IV Congreso Nacional El conocimiento como espacio de encuentro (pp. 51-62). Neuquén: Universidad Nacional del Comahue.

Gu, P. Y. (2020). Strategies for learning vocabulary. In S. Webb (Ed.), The Routledge handbook of vocabulary studies (pp. 271-287). Abingdon/New York: Routledge.

Halliday, M. A. K. \& Hasan, R. (1976). Cohesion in English. London: Longman.

Halliday, M. A. K. (1978). Language as social semiotic. London: Arnold.

Halliday, M. A. K. (2004). An introduction to functional grammar. London: Arnold.

Hanks, J. (2019). From research-as-practice to exploratory practice-as-research in language teaching and beyond. Language Teaching, 52(2), 143-187.

Innocentini, V., \& Forte, A. (2016). An experience with "blended learning" at college: Can we define criteria to support its adoption? ARTESOL EFL E-Journal 1(3), 4-8.

Innocentini, V., Forte, A. \& Feraco, M. (2017). An ongoing experience with the use of hypothetical situations as part of an ESP reading comprehension course: the case of agricultural engineering students. ARTESOL ESP E-journal, 7(1), 3 -14.

Insirillo, P., \& P. Ortiz (2018). Exploring students' vocabulary learning strategy profile at the beginning of reading comprehension courses at university level. ARTESOL ESP EJournal, 3(1), 27-45.

Kumaravadivelu, B. (2003). A postmethod perspective on English language teaching. World Englishes, 22, 539-550.

Laucírica, A. (2016). El inglés oral: estrategias comunicativas y conocimiento declarativo. In M. Gastaldi \& E. Grimaldi (Eds.), Políticas lingüísticas y lenguas extranjeras en el nivel superior (pp. 621-629). Santa Fe: Universidad Nacional del Litoral.

Levia, T., \& Inbar-Lourie, O. (2020). Assessment literacy or language assessment literacy: Learning from the teachers. Language Assessment Quarterly, 17(2), 168-182. Li, L. (2017). New technologies and language learning. London: Palgrave.

This is a peer-reviewed, author-accepted manuscript of the following research article: Porto, M., López-Barrios, M., \& Banegas, D. (2021). Research on English language teaching and learning in Argentina (2014-2018). Language Teaching, 1-33. 
Lightbown, P. M. \& Spada, N. (2006). How Languages are Learned (3rd ed.). Oxford: OUP. López Casoli, M. \& Berardo, E. (2017). Devolución escrita indirecta: ¿las preguntas sirven como estrategia para guiar el proceso de escritura en inglés como lengua extranjera? In D. Riestra (Ed.), Quintas Jornadas Internacionales de Investigación y Prácticas en Didáctica de las lenguas y las literaturas (pp. 1034-1047). Viedma: Editorial UNRN.

López Casoli, M. \& Borgnia, C. (2018). El uso de conectores según los géneros textuales en la escritura académica en inglés como lengua extranjera. In F. Perduca. (Ed.), Actas de las IV Jornadas Internacionales sobre formación e investigación en lenguas y traducción: lenguas en el cruce de fronteras: políticas, prácticas y saberes (pp. 94-99). Buenos Aires: Instituto de Enseñanza Superior en Lenguas Vivas Juan Ramón Fernández.

López Casoli, M., \& Berardo, E. (2018). Percepciones docentes sobre las prácticas de devolución en la escritura académica en inglés como lengua extranjera. In F. Perduca. (Ed.), Actas de las IV Jornadas Internacionales sobre formación e investigación en lenguas y traducción: lenguas en el cruce de fronteras: políticas, prácticas y saberes (pp. 298-305). Buenos Aires: Instituto de Enseñanza Superior en Lenguas Vivas Juan Ramón Fernández.

López Casoli, Marina; Selesán, Marina C., Text Type and Connector Use in EFL Expository Writing. ARTESOL EFL E-Journal 1(3), 42-52.

Lopez, S. I. \& Viejobueno, M. (2017) Adquisición de algunos patrones sintácticos no canónicos en lengua inglesa. In M. Barbeito, M. López-Barrios \& R. Pasquale (Eds.), Lenguas y culturas: Desafios actuales de la diversidad y de la integración. Actas de las XV Jornadas y II Congreso Latinoamericano de Enseñanza de Lenguas Extranjeras en el Nivel Superior (Vol. III, pp.141-156). Córdoba: Universidad Nacional de Córdoba.

Machado, C. \& Lucas, S. (2017). El Feedback indirecto en el proceso de escritura en inglés:

This is a peer-reviewed, author-accepted manuscript of the following research article: Porto, M., López-Barrios, M., \& Banegas, D. (2021). Research on English language teaching and learning in Argentina (2014-2018). Language Teaching, 1-33. 
implicancias pedagógicas. In D. Riestra (Ed.), Quintas Jornadas Internacionales de Investigación y Prácticas en Didáctica de las lenguas y las literaturas (pp. 1048-1059). Viedma: Editorial UNRN.

Machado, C., Lucas, S. \& Berardo, E. (2017). El feedback comprensivo y selectivo y el proceso de escritura en inglés. In. M. Romano \& B. Amado (Eds.), Lenguas y culturas: Desafios actuales de la diversidad y de la integración. Actas de las XV Jornadas y II Congreso Latinoamericano de Enseñanza de Lenguas Extranjeras en el Nivel Superior (Vol. I, pp. 125-135). Córdoba: Universidad Nacional de Córdoba.

Mahmoudi, S., \& Mahmoudi, A. (2015). Internal and External Factors Affecting Learning English as a Foreign Language. International Journal of Language and Linguistics, 3(5), 313-322.

Marconi, A. (2016). Formación docente: una propuesta de trabajo colaborativo intercátedra. LyCE Estudios, 19, 21-33.

Martin, J. R., \& Rose, D. (2008). Genre relations: Mapping culture. London: Equinox.

Martin, J. R., \& White, P. R. (2005). Language of evaluation: Appraisal in English. London: Palgrave Macmillan.

Martínez, I. \& Picchio, R. (2014). Genre-based reading course for masters students in an EFL context. ARTESOL ESP E-journal, 4(1), 30-36.

Martino, G. (2014). What boys and girls like: Favorite topics and tasks for primary school learners. ARTESOL EFL E-Journal, 1(1), 22-27.

Massa, A., Morchio, M. J., \& Schander, M. (2016). La calidad tecnopedagógica y el material didáctico en el aula virtual: Resultados de un proyecto de investigación. In M. Gastaldi \& E. Grimaldi (Eds.), Políticas lingüisticas y lenguas extranjeras en el nivel superior (pp. 317-326). Santa Fe: Universidad Nacional del Litoral.

Mayol, C. E. (2014). Learners' voices: Their contributions to language teaching. In D. L.

This is a peer-reviewed, author-accepted manuscript of the following research article: Porto, M., López-Barrios, M., \& Banegas, D. (2021). Research on English language teaching and learning in Argentina (2014-2018). Language Teaching, 1-33. 
Banegas, M. López-Barrios, M. Porto \& M. A. Soto (Eds.), English language teaching in the post-methods era: Selected papers from the 39th FAAPI Conference (pp. 155170). Santiago del Estero: APISE.

Mickan, P., \& Wallace, I. (Eds.). (2020). The Routledge handbook of language education curriculum design. Abingdon/New York: Routledge.

Montserrat, M., \& Mórtola, G. (2018). La enseñanza del inglés para las grandes mayorías nacionales en Argentina. Revista Digital de Políticas Lingüísticas, 10, 167-191.

Moyetta, D. (2017). Tipologización de géneros académicos en inglés en el ámbito del Diseño Industrial. In D. Moyetta, C. Raffo \& S. Rezzano (Eds.), Lenguas y culturas: Desafios actuales de la diversidad y de la integración. Actas de las XV Jornadas y II Congreso Latinoamericano de Enseñanza de Lenguas Extranjeras en el Nivel Superior (Vol. V, pp. 225-240). Córdoba: Universidad Nacional de Córdoba.

Mulone, M. V. (2017). Building the teacher professional identity: From college to classroom. ARTESOL EFL E-Journal, 1(4), 10-22.

Natal, M., Suárez, P., \& Tuero, S. (2016). El rol de las colocaciones en los libros de textos de inglés: Práctica, revisión y evaluación. In M. Gastaldi \& E. Grimaldi (Eds.), Políticas lingüísticas y lenguas extranjeras en el nivel superior (pp. 327-335)..Santa Fe: Universidad Nacional del Litoral.

Oliva, M. B. \& de Maussion, A. (2017). El uso de verbos por parte de ingresantes a la universidad en un género particular. In. M. Romano \& B. Amado (Eds.), Lenguas y culturas: Desafios actuales de la diversidad y de la integración. Actas de las XV Jornadas y II Congreso Latinoamericano de Enseñanza de Lenguas Extranjeras en el Nivel Superior (Vol. I, pp. 97-108). Córdoba: Universidad Nacional de Córdoba.

Organisation of American States (2011). Tenth anniversary of the Inter-American Democratic Charter. A hemispheric commitment to democracy. OAS official records.

This is a peer-reviewed, author-accepted manuscript of the following research article: Porto, M., López-Barrios, M., \& Banegas, D. (2021). Research on English language teaching and learning in Argentina (2014-2018). Language Teaching, 1-33. 
Available from:

http://www.oas.org/docs/publications/Tenth\%20Anniversary $\% 20$ of $\% 20$ the $\% 20$ InterAmerican\%20Democratic\%20Charter.pdf

Organisation of American States. Summits of the Americas Mandates on Democracy 19942018. Available from: http://www.summit-americas.org/sisca/dem.html

Orta González, M. D., \& Castro, A. M. (2017). Tecnologías aplicadas a la enseñanza de inglés: Análisis de las percepciones y construcción de algunos entornos de aprendizaje virtual como complementos de la educación presencial universitaria. In I. Lanzi de Zeitune \& N. Villagra Márquez (Eds.), Reflexiones sobre la lengua y propuestas prácticas sobre la didáctica del inglés (pp. 92-104). San Miguel de Tucumán: Universidad Nacional de Tucumán.

Panzachi Heredia, D. (2017). Impact of nuclear stress and its placement on non-native speakers' difficulty to process oral discourse. In M. Fernández Beschtedt, A. Castro, P. Formiga, \& Z. Risso Patrón (Eds.), Zonas de contacto: culturas, lenguas y educación: Actas IV Congreso Nacional El conocimiento como espacio de encuentro (pp. 152162). Neuquén: Universidad Nacional del Comahue.

Pekrun, Goetz, Titz \& Perry (2002). Academic emotions in students' self-regulated learning and achievement: A program of qualitative and quantitative research. Educational Psychologist, 37, 91-106.

Pekrun, R. (2014). Emotions and learning. Educational Practices Series, 24. Geneva:

Percara, A. (2015). Benefits and drawbacks of supervisory feedback in the teaching practicum: Student teachers' perceptions. ARTESOL EFL E-Journal, 1(2), 17-23.

Pérez, J. \& Zinkgraf, M. (2017). What Goes Around Comes Around: a Corpus Study of Formulaic Sequences in Advanced Students’ Written Production. In M. Fernández Beschtedt, A. Castro, P. Formiga, \& Z. Risso Patrón (Eds.), Zonas de contacto:

This is a peer-reviewed, author-accepted manuscript of the following research article: Porto, M., López-Barrios, M., \& Banegas, D. (2021). Research on English language teaching and learning in Argentina (2014-2018). Language Teaching, 1-33. 
culturas, lenguas y educación: Actas IV Congreso Nacional El conocimiento como espacio de encuentro (pp. 88-98). Neuquén: Universidad Nacional del Comahue.

Perticone, A. (2017). The Acquisition of an L2 Phonology: Theoretical Models, Research Findings and Pronunciation Teaching. In M. Fernández Beschtedt, A. Castro, P. Formiga, \& Z. Risso Patrón (Eds.), Zonas de contacto: culturas, lenguas y educación: Actas IV Congreso Nacional El conocimiento como espacio de encuentro (pp. 163172). Neuquén: Universidad Nacional del Comahue.

Pico, M. L. \& Sleibe Rahe de Paradelo, A. (2017). Géneros textuales en L1 y L2. Aportes para la competencia escrita en inglés. Resultados finales. In. M. Romano \& B. Amado (Eds.), Lenguas y culturas: Desafios actuales de la diversidad y de la integración. Actas de las XV Jornadas y II Congreso Latinoamericano de Enseñanza de Lenguas Extranjeras en el Nivel Superior (Vol. I, pp. 109-124). Córdoba: Universidad Nacional de Córdoba.

Piquer, V., Ponce, S. \& Padula, M. (2017). Creencias acerca del aprendizaje de lenguasculturas de alumnos ingresantes: Su evolución en una carrera plurilingüe. In M. Baduy, A. Bogliotti, M. Ledesma \& A. Pérez (Eds.), Lenguas y culturas: Desafios actuales de la diversidad y de la integración. Actas de las XV Jornadas y II Congreso Latinoamericano de Enseñanza de Lenguas Extranjeras en el Nivel Superior (Vol. VI, pp. 31-41). Córdoba: Universidad Nacional de Córdoba.

Porto, M. (2014). The role and status of English in Spanish-speaking Argentina and tts education system: Nationalism or imperialism? SAGE Open, 1-14.

Porto, M., \& Byram, M. (2017). New perspectives on intercultural language research and teaching: Exploring learners' understandings of texts from other cultures. With foreword by Henry Widdowson. London: Routledge.

Porto, M., Montemayor-Borsinger, A., \& López-Barrios, M. (2016). Research on English

This is a peer-reviewed, author-accepted manuscript of the following research article: Porto, M., López-Barrios, M., \& Banegas, D. (2021). Research on English language teaching and learning in Argentina (2014-2018). Language Teaching, 1-33. 
language teaching and learning in Argentina (2007-2013). Language Teaching, 49(3), 356-389.

Regueira, A. L., Del Potro, A., \& Di Virgilio, A. (2018). Conceptualizaciones de contextos pedagógicos: ¿Cómo afectan al uso del inglés en el aula? Lenguas V;vas, 14, 10- 22.

Regueira, A., Williams, J. \& Caielli, E. (2017). Propuesta de evaluación criterial para medir la lectocomprensión en inglés al finalizar la escuela secundaria. In F. Ávalos, H. Gargiulo, J. Rodríguez \& E. Villanueva de Debat, (Eds.) (2017). Desafios actuales de la diversidad y de la integración. Actas de las XV Jornadas y II Congreso Latinoamericano de Enseñanza de Lenguas Extranjeras en el Nivel Superior. Volumen II (pp. 30-40). Córdoba: Universidad Nacional de Córdoba.

Requena, P., Liruso, S., \& Bollati, M. (2016). The young learner's textbook as a visual model of Interaction. In D. L. Banegas, M. López-Barrios, M. Porto \& M. A. Soto (Eds.), ELT as a multidisciplinary endeavour: Growing through collaboration. Selected papers from the 41st FAAPI Conference (pp. 29-39). San Juan: ASJPI.

Roccia, V., \& F. Sacchi, F. (2015). Teachers' beliefs about technology and curriculum design: A multiple case study. In M. Somale (Ed.), Selected papers from the III ELT conference at U.N.V.M (pp. 96-103). Villa María: Universidad Nacional de Villa María.

Rodeghiero, A. C. (2017). The impact of formulaic sequence instruction on beginner EFL students’ biography writing: A case study. In M. Fernández Beschtedt, A. Castro, P. Formiga, \& Z. Risso Patrón (Eds.), Zonas de contacto: culturas, lenguas y educación: Actas IV Congreso Nacional El conocimiento como espacio de encuentro (pp. 77-87). Neuquén: Universidad Nacional del Comahue.

Rodríguez, S., Castro, A., García Alvarez, A., Scilipoti, P., \& Tacconi, L. (2015). Reflexionar para crecer: Promoviendo una actitud crítica en futuros profesores de inglés. In A. Castro, P. Formiga, Z. Risso Patron (Eds.), Plurilingüismo, diversidad e

This is a peer-reviewed, author-accepted manuscript of the following research article: Porto, M., López-Barrios, M., \& Banegas, D. (2021). Research on English language teaching and learning in Argentina (2014-2018). Language Teaching, 1-33. 
interculturalidad: un acercamiento desde la educación, traducción e investigación: Actas del III Congreso Nacional El conocimiento como espacio de encuentro (nd). Neuquén: Universidad Nacional del Comahue. Facultad de Lenguas.

Romano, M. \& Martínez, J. (2017). Evaluación de la escritura en lengua extranjera (inglés): Análisis de criterios docentes. In F. Ávalos, H. Gargiulo, J. Rodríguez \& E. Villanueva de Debat, (Eds.) (2017). Desafíos actuales de la diversidad y de la integración. Actas de las XV Jornadas y II Congreso Latinoamericano de Enseñanza de Lenguas Extranjeras en el Nivel Superior (Vol. II, pp. 78-90). Córdoba: Universidad Nacional de Córdoba.

Rose, D., \& Martin, J. (2012). Learning to write, reading to learn: Genre, knowledge and pedagogy in the Sydney School. London: Equinox.

Rowsell, J., \& Vietgen, P. (2017). Embracing the unknown in community arts zone visual arts. Pedagogies: An International Journal, 12(1), 90-107.

Salcedo, N., \& Sacchi, F. (2014). The role of culture in the EFL classroom: A study of teachers' beliefs and practices. In D. L. Banegas, M. López-Barrios, M. Porto \& M. A. Soto (Eds.), English language teaching in the post-methods era: Selected papers from the $39^{\text {th }}$ FAAPI Conference (pp. 81-91). Santiago del Estero: APISE.

San Martín, G., Faletti, P., \& Helale, G. (2016). Significados ideacionales en el discurso del feedback docente. In C. Padilla Sabaté \& D. Riestra (Eds.), Problemáticas en enseñanza y aprendizaje de lenguas (pp. 252-277). Bahía Blanca: Editorial de la Universidad Nacional del Sur. Ediuns, Sociedad Argentina de Lingüística.

San Martín, M. G., \& Helale, G. (2017). El aprendizaje léxico en la escuela secundaria pública: Análisis de creencias y uso de estrategias. In M. C. Barbeito, M. López-Barrios \& R. Pasquale (Eds.), Lenguas y culturas: Desafios actuales de la diversidad y de la integración. Actas de las XV Jornadas y II Congreso Latinoamericano de Enseñanza de

This is a peer-reviewed, author-accepted manuscript of the following research article: Porto, M., López-Barrios, M., \& Banegas, D. (2021). Research on English language teaching and learning in Argentina (2014-2018). Language Teaching, 1-33. 
Lenguas Extranjeras en el Nivel Superior (Vol. III, pp. 87-100). Córdoba: Universidad Nacional de Córdoba.

San Martín, M., Altamirano, M. \& Villanueva de Debat, E. (2016). Adolescent and adult EFL learners' vocabulary learning and teaching beliefs. In D. L. Banegas, M. López Barrios, M. Porto, \& A. Soto (Eds.), ELT as a multidisciplinary endeavour: selected Papers from the XLI FAAPI Conference (pp. 139-149). San Juan: Universidad Nacional de San Juan. Facultad de Filosofía, Humanidades y Artes.

Sapag, N. \& Boldrini, S. (2017). How authentic is the vocabulary dealt with in class? In D. Banegas, M. López-Barrios, M. Porto \& D. Waigandt (Eds.), Authenticity in ELT: selected papers from the 42nd FAAPI Conference (pp. 130-138). Posadas: APIM.

Sarasa, M. C. (2014). Experiencias de enseñanza y de aprendizaje mediante la investigación biográfica y la indagación narrativa. Revista de Educación, 7, 157-170.

Sarasa, M. C. (2017). Las posibilidades descolonizadoras de las narrativas en la formación inicial del profesorado. Revista de Educación, 12, 49-66.

Sarasa, M. C., \& Solís, D. (2017). Narrating the temporalities, localities, and socialities of future English teachers' professional identities. Argentinian Journal of Applied Linguistics, 5(2), 21-39.

Sergi, V. (2017). La enseñanza del inglés en un contexto intercultural y pensamiento crítico. Las actividades del lead-in en libros de texto para la preparación del examen Advanced de la Universidad de Cambridge. Cronía, 13, 32-44.

Solier, M. L. (2015). Critical thinking in learning aims: An analysis from the revised Bloom's taxonomy. ARTESOL EFL E-Journal, 1, 33-38.

Soto, M. A. (2014). Post-method pedagogy: Towards enhanced context-situated teaching methodologies. In D. L. Banegas, M. López-Barrios, M. Porto \& M. A. Soto (Eds.), English language teaching in the post-methods era: Selected papers from the 39 th

This is a peer-reviewed, author-accepted manuscript of the following research article: Porto, M., López-Barrios, M., \& Banegas, D. (2021). Research on English language teaching and learning in Argentina (2014-2018). Language Teaching, 1-33. 
FAAPI Conference (pp. 39-54). Santiago del Estero: APISE.

Soto, M. A., \& Waigandt, D. M. (2018). Affectivity and oral presentations: Catering for individual learner needs. In D. L. Banegas, M. López-Barrios, M. Porto \& D. Waigandt (Eds.), Adapting to meet diverse needs in ELT: Selected Papers from the 43rd FAAPI Conference (8-16). Río Gallegos: ASCPI.

Spataro, C. (2015). Using ICT to improve perception skills in EFL listening. In L. Anglada, N. L. Sapag, D. L. Banegas \& M. A. Soto (Eds). EFL classrooms in the new millennium: Selected papers from the 40th FAAPI Conference (pp. 81-97). Córdoba: ACPI.

Suárez, P., \& Tuero, S. (2015). Analyzing the selection and presentation of collocations in an EFL textbook. ARTESOL EFL E-Journal, 1(2), 4-11.

Suárez, P., Tuero, S., \& Natal, M. (2017). Collocations: A comparison between intermediate and upper-intermediate textbooks. ARTESOL EFL E-Journal 1(4), 4-9.

Tavella, G. N., \& Fernández, C. (2017). ¿Cuál es el rol del docente de Lenguas con Propósitos Específicos en la era postmétodo? In D. Moyetta, C. Raffo \& S. Rezzano (Eds.), Lenguas y culturas: Desafios actuales de la diversidad y de la integración. Actas de las XV Jornadas y II Congreso Latinoamericano de Enseñanza de Lenguas Extranjeras en el Nivel Superior (Vol. V, pp. 276-288). Córdoba: Universidad Nacional de Córdoba.

UNESCO (2015). Rethinking education. Towards a global common good? Paris: UNESCO Publishing.

Valcarce, M., \& Fernández, S. G. (2017). There is something new under the sun in biography writing and vocabulary teaching: a preliminary study. In M. Fernández Beschtedt, A. Castro, P. Formiga, \& Z. Risso Patrón (Eds.), Zonas de contacto: culturas, lenguas y educación: Actas IV Congreso Nacional El conocimiento como espacio de encuentro

This is a peer-reviewed, author-accepted manuscript of the following research article: Porto, M., López-Barrios, M., \& Banegas, D. (2021). Research on English language teaching and learning in Argentina (2014-2018). Language Teaching, 1-33. 
(pp. 63-76). Neuquén: Universidad Nacional del Comahue.

Valenti, V., \& Galimberti, M. (2015). ESP: From grammar translation lessons to learnercentred blended learning lessons. In L. Anglada, N. L. Sapag, D. L. Banegas \& M. A. Soto (Eds). EFL classrooms in the new millennium: Selected papers from the 40th FAAPI Conference (pp. 70-80). Córdoba: ACPI.

Valsecchi, M. I., Sacchi, F., Salcedo, N., Baldocchi, B., \& Roccia, V. (2016). Creencias de docentes de inglés sobre cultura, tecnología y escritura en la escuela secundaria. In G. Maldonado, A. Bono, \& D. Sigal (Eds.), Qué investigamos en la Facultad de Ciencias Humanas: Actas de las Jornadas de Investigación de la Facultad de Ciencias Humanas 2015 (pp. 318-332). Río Cuarto: UniRío Editora.

Varela, L., \& Verdelli, A. (2016). Las lenguas extranjeras en el mapa escolar de la Ciudad de Buenos Aires. In M. Gastaldi \& E. Grimaldi (Eds.), Políticas lingüísticas y lenguas extranjeras en el Nivel Superior (pp. 61-70). Santa Fe: Universidad Nacional del Litoral.

Vázquez, D. \& González, M. (2015). The Impact of Instructional Format on Reading Comprehension: Cognitive Load Theory and the Redundancy Effect. ARTESOL EFL EJOURNAL, 1(2), 24-32.

Vázquez, D. \& González, M. (2016). Sentence Stress and Segmental Features’ Impact on Comprehension and Intelligibility. ARTESOL EFL E-JOURNAL, 1(3), 24-30.

Vázquez, D. \& González, M. (2018). Note-taking Instruction: Its Impact on Recall of Main Ideas. ARTESOL EFL E-JOURNAL, 2(1), 19-32.

Wagner, M., Conlon Perugini, D., \& Byram, M. (Eds.). (2018). Teaching intercultural competence across the age range: From theory to practice. Bristol: Multilingual Matters.

Walsh, S., \& Mann, S. (Eds.). (2019). The Routledge handbook of English language teacher

This is a peer-reviewed, author-accepted manuscript of the following research article: Porto, M., López-Barrios, M., \& Banegas, D. (2021). Research on English language teaching and learning in Argentina (2014-2018). Language Teaching, 1-33. 
education. Abingdon/New York: Routledge.

Warschauer, M., Zheng, B. \& Y. Park (2013). New ways of connecting reading and writing. TESOL Quarterly, 47, 825-830.

Yuni, J., \& Díaz, A. G. (2015). Pedagogías de la formación docente y construcciones metodológicas: o sobre diferentes modos de configurar la formación de los docentes. Revista de Educación, 8, 157-182.

Zinkgraf, M. \& Verdú, M. (2015). Formulaic sequences involving 'fact' in EAP production: A corpus study. In L. Anglada, N. Sapag, D. Banegas \& M. Soto (Eds). EFL classrooms in the new millennium: selected papers from the 40th FAAPI Conference (pp. 58-69). Córdoba: ACPI.

Zinkgraf, M. \& Verdú, M. (2017). On track: variations in EFL learners' formulaic sequence use. In M. Fernández Beschtedt, A. Castro, P. Formiga, \& Z. Risso Patrón (Eds.), Zonas de contacto: culturas, lenguas y educación: Actas IV Congreso Nacional El conocimiento como espacio de encuentro (pp. 99-112). Neuquén: Universidad Nacional del Comahue.

Zinkgraf, M., Rodríguez, S., Castro, A. \& Verdú, M. (2015). New perspectives on vocabulary: Formulaic sequences in the structuring of advanced learners' written production. In A. Castro, P. Formiga, Z. Risso Patron (Eds.), Plurilingüismo, diversidad e interculturalidad: un acercamiento desde la educación, traducción e investigación: Actas del III Congreso Nacional El conocimiento como espacio de encuentro (nd). Neuquén: Universidad Nacional del Comahue. Facultad de Lenguas.

This is a peer-reviewed, author-accepted manuscript of the following research article: Porto, M., López-Barrios, M., \& Banegas, D. (2021). Research on English language teaching and learning in Argentina (2014-2018). Language Teaching, 1-33. 